\title{
Immune-Endocrine Interactions in the Fish Gonad during Infection: An Open Door to Vertical Transmission
}

\author{
Yulema Valero ${ }^{1}$ (D), Alberto Cuesta ${ }^{2}$ (D), Matteo Cammarata ${ }^{3}$, María Angeles Esteban ${ }^{2}$ (D) and \\ Elena Chaves-Pozo $4, *$ (iD
}

1 Grupo de Marcadores Inmunológicos, Laboratorio de Genética e Inmunología Molecular, Instituto de Biología, Pontificia Universidad Católica de Valparaíso, 2340025 Valparaíso, Chile; yulema.valero@pucv.cl

2 Fish Innate Immune System Group, Department of Cell Biology and Histology, Faculty of Biology, Campus Regional de Excelencia Internacional “Campus Mare Nostrum”, University of Murcia, 30100 Murcia, Spain; alcuesta@um.es (A.C.); aesteban@um.es (M.A.E.)

3 Marine Immunebiology Laboratory Department of Earth and Marine Science, University of Palermo, Viale delle Scienze ED. 16, Conisma, 90133 Palermo, Italy; matteo.cammarata@unipa.it

4 Centro Oceanográfico de Murcia, Instituto Español de Oceanografía (IEO), Carretera de la Azohía s/n, Puerto de Mazarrón, 30860 Murcia, Spain

* Correspondence: elena.chaves@ieo.es; Tel.: +34-968-153-973

Received: 3 May 2018; Accepted: 7 June 2018; Published: 13 June 2018

\begin{abstract}
The interaction between the immune and endocrine systems has long been recognized in vertebrates. In fish, it is known that the prevalence and intensity of such infections are higher in males than in females and probably related to sex steroid hormone levels. In addition, the immune response in the fish gonad tissues is specifically regulated to prevent infertility. This condition is used by some pathogens to colonize the fish gonad, evade the systemic immune response, and so spread to the progeny. This review brings up to date our knowledge concerning fish gonad immunity and its regulation, immune-endocrine interactions, and how some pathogens use this tissue to spread to the progeny through vertical transmission. More specifically, we will look at the case of the European sea bass and nodavirus (NNV). Sea bass is a very susceptible fish species to NNV infections, and this virus has been associated to vertical transmission since it is detected in gonad fluids as well as in testicular gametes. In fact, sea bass immunity in the gonad is regulated in a very different way to other target tissues (brain and retina) or immune-relevant tissues (head-kidney or spleen).
\end{abstract}

Keywords: fish; immunity; endocrinology; immune-endocrine interaction; gonad; disease; nodavirus; maternal transfer

\section{Introduction}

In times when extractive fishing covers around $50 \%$ of human needs and fish protein requirements by humans is increasing, fish farming appears as the most promising industry to satisfy this need [1]. However, the confinement of large numbers of specimens in a reduced space in farming facilities and the regular handling involved expose the animals to stress conditions, weakening their immune system, increasing their susceptibility to pathogens, and, in turn, leading to the emergence of diseases caused by opportunistic pathogens. In addition, the global movement of eggs, larvae, juveniles, and fish by-products between facilities worldwide favors the spread of pathogens, resulting in serious economic losses [2-4]. Both in wild conditions and in farms, fish pathogens evolve to survive and spread. Captivity provides fish with a wide range of conditions that give rise to stress situations that 
fish usually do not suffer in the wild, affecting a range of physiological mechanisms. In aquaculture, bacteria are the most usual cause of diseases; however, viruses, parasites, and fungi also have an important impact in fish farms. Although bacteria are the most common pathogens, viruses are the most threatening since they are difficult to control and few preventive or palliative treatments are available [5].

In vertebrates, the prevalence and intensity of infections are higher in males than females [6]. This sex dependence in resisting infection could at first sight be related to sex steroid hormone levels. In this regard, alterations in androgen, estrogen, and vitellogenin serum levels have been commonly documented in fish after infection [7]. As an example, silver seabream (Sparus sarba) specimens suffering a vibriosis outbreak showed an increase in testosterone $(\mathrm{T})$ serum levels as the infection progressed, while estradiol $\left(\mathrm{E}_{2}\right)$ was found to sharply decrease in moribund fish [8]. Additionally, the exogenous administration of $\mathrm{E}_{2}$ decreased the survival rates of Yersinia-infected rainbow trout (Oncorhynchus mykiss) in an $\mathrm{E}_{2}$-dependent dose-manner [9]. It is clear that hormones such as cortisol, growth hormone $(\mathrm{GH})$, prolactin (PRL), some proopiomelanocortin-derived peptides, and reproductive hormones from all the levels of the neuroendocrine reproductive axis regulate leucocyte functions and different immune responses in several fish species. Although the effects of all these endocrine mediators on the immune system are not completely understood in fish, our knowledge of these issues has recently been reviewed by several research groups (see for review [10-17]). Moreover, little is known about how the immune response is regulated within the reproductive tissues in fish. A different sex implies differences in gonad physiology and different profiles of sex hormones, with a consequent variety in any immune regulation. Gonad physiology takes on even greater importance for the strategies used by pathogens to spread, especially in the case of vertical transmission (transmission to the next generation). Such vertical transmission of pathogens occurs in all vertebrate phyla and consists of the spread of pathogens to the next generation, where they may be found in gonad fluids or inside gametes (vertical transmission sensu stricto). The special immune conditions in the gonad environment appear to be important for pathogen colonization and survival inside the host and, in some cases, to promote their vertical transmission. Moreover, the ability of pathogens to alter steroidogenesis and therefore fish susceptibility to disease is very important for this kind of pathogen. In this review, we document the special regulation of the immune response in the reproductive tissues and the role of these organs in pathogen survival and transmission in fish. We review the pathogens known to infect teleost fish gonads and look at the evidence, mainly using the nodavirus (NNV)/European sea bass (Dicentrarchus labrax) model, concerning how pathogens might modify both reproductive and immune systems through neuroendocrine regulation pathways in order to take advantage in their resistance and spread.

\section{Immune Privilege and the Immune Response in the Gonad}

An immune-privileged tissue is defined as a tissue able to extend the survival of cells expressing antigens that in other tissues would trigger an immune response. The mechanism by which this is made possible not only involves the blood-tissue barrier, as previously thought, but is also due to the specific regulation of immunity in the gonadal environment [18]. Unlike the blood-testis barrier, the ovary has no blood-tissue barrier through specialized interactions against adjacent cells [19]. However, the immune system does not respond to zona pellucida proteins expressed by the developing oocytes. Moreover, inflammation is a well-known process essential for oocyte release during ovulation including the migration of leucocytes into the follicle [20]. Evidence found in both testis and ovary points to a special regulation of the immune response in these tissues, including increased tolerance through the depletion of immune-reactive cells [19-22].

\subsection{The Blood-Testis Barrier}

The blood-tissue barriers are located in several tissues such as brain, testis, retina, or gut. Most of them are formed by tight junctions (TJ) of adjacent endothelial cells of microvessels that regulate 
the transport of substances and cells across the barrier and inside the organ [23]. However, the testis-barrier is quite different, as it is formed by TJs between Sertoli cells and is located at the basal region of the seminal epithelium [24]. This barrier allows sealing post-meiotic germ cells in a highly specialized environment as the barrier blocks the entry of molecules, or even pumping them out or in through a specific network of transporters [25]. The pre-meiotic germ cells and all the vascular endothelium, including Leydig cells, are located on the exterior of the barrier. The development of germ cells involves the continuous disassembly and reassembly of this barrier, which is tightly controlled by several signaling pathways involving hormones and cytokines (reviewed by [23,26,27]). Several viruses have been demonstrated to disrupt the blood-testis barrier and are able to colonize the specialized environment in which the admission of antiviral molecules is highly restricted by means of the restrictive paracellular and transcellular diffusion of molecules, creating a reservoir tissue to hide the virus and evade the immune response [28,29]. Moreover, the existence of drug transporters able to pump out antiviral or pharmacological drugs allows viral levels to remain high enough in the testis or brain even when the virus is almost undetected in other organs [25,30]. Moreover, some viruses such as Zika virus preferably infect Sertoli and germ cells located at the basal compartment of the seminiferous epithelium in mice [28]. Given the presence of gap junctions between Sertoli and germ cells in mammalian testes [31], it is easy for this virus to cross the blood-testis barrier.

As in mammals, Sertoli cells in the fish testis are attached to one each other by specialized cell junctions, although they are not as specialized as mammalian ones [32]. As the fish testis is a cystic structure in which a cohort of germ cells is surrounded by a cohort of Sertoli cells, the blood-testis barrier is only organized in those cysts that contain post-meiotic germ cells [33], so the transition of germ cells through the blood-testis barrier does not take place in fish. Fish Sertoli-Sertoli cells junctions develop as the germ cells enclosed by them progress in the spermatogenetic process. Thus, when only spermatogonia are enclosed, intermediate junctions, gap junctions, and desmosomes form the contact region between Sertoli cells. However, tight junctions are only observed between Sertoli cells in the cyst containing spermatids but not primary spermatocytes. Therefore, meiotic germ cells are not shielded from the vascular compartment. Interestingly, the unique adhesion junctions observed in the mammalian testis and known as the "ectoplasmic specialization" have not been observed in the fish species studied to date. Any differences between fish species described not only refer to the morpho-functional characteristics but also to the molecular composition of Sertoli-Sertoli cell adhesion structures (see for review [32,34]). The appearance of tight junctions only in the cyst containing spermatids in all the fish species studied has led to the postulation that the main function of the Sertoli cells barrier in fish testis might be to develop a highly specialized microenvironment for haploid germ cells $[35,36]$. Sertoli cells are also connected with germ cells by gap junctions that allow the control of the spermatogenetic process by the Sertoli cells $[37,38]$.

\subsection{Immune Effectors Out of the Blood-Testis Barrier}

It is now known that the gonads are not organs depleted of immune cells. Thus, in mammals, the testes have effective lymphatic vessels that drain directly to local lymph nodes [39-41]. Moreover, macrophages, lymphocytes, and dendritic, eosinophilic, and mast cells are located in the testicular interstitium [22], and most experimental xenografts are also able to survive for longer than in other tissues in rats, mice, and Guinea pig testes [42-44]. Interestingly, the interstitial tissue of the testis expresses both major histocompatibility complex (MHC) class I and II molecules, and the vascular endothelium allows the trafficking of immune cells and immune effectors (cytokine, immunoglobulin, and complement proteins) into the testis [45-48]. Both myeloid and lymphoid immune cell types have been described in the testicular interstitium in several fish species, where differences in the number of leucocytes have been reported for different reproductive stages (reviewed by [49]). In the testicular area of the gonad of the hermaphrodite seasonally breeding gilthead seabream (Sparus aurata), acidophilic granulocytes, macrophages, B and T lymphocytes, and mast cells have been described $[49,50]$. As occurs in mammals, the testis of gilthead seabream and European sea bass expresses the genes 
coding for pro- and anti-inflammatory cytokines, chemokines, immunoglobulins, complement factors, antimicrobial peptides (AMPs), immune receptors such as Toll-like receptors (TLRs), and T cell receptor (TCR), as well as molecules involved in the antiviral response [49,51]. In addition, gonadal-specific molecules related with immune-endocrine interactions have been described in other fish species. Thus, ovary and testis specific insulin-like growth factor (IGF)-3 has been detected in Nile tilapia (Oreochromis niloticus) [52]. Changes in the gene expression of IGFs in immune tissues have been related to the immune response against Yersinia infections and are modified upon $\mathrm{E}_{2}$ treatment in a tissue-dependent manner [9]. Moreover, in rainbow trout females, interferon (IFN)-3/4 show restricted high expression in the ovary $[53,54]$. Interestingly, the disability of pathogens to up-regulate the expression of IFN genes has been related with the establishment of latent infections in the ovary of rainbow trout [55]. Regarding gonad-specific AMPs, in the testis of mudskipper (Boleophthalmus pectinirostris) two hepcidins have been described. Interestingly, hepcidin-2 is highly produced in Leydig cells, regulated by gonadotrophins, and up-regulated upon lipopolysaccharide (LPS) stimulation [56]. In the orange-spotted grouper (Epinephelus coioides), a $\beta$-defensin specifically expressed in pituitary and testis has also been cloned [57].

\subsection{The Testicular Environment that Allows Immune Privilege}

There is evidence in mammals that the active tolerance of the immune response in the testes is due to its ability to regulate immunity. Thus, foreign grafts survive longer in the testis than in other sites, even when most experiments positioned the grafts in the interstitial compartment of the testis and not inside the blood-testis barrier [22]. Moreover, testicular explants that include Sertoli cells are able to avoid the immune response when transplanted into various tissues [58]. Likewise, they display inhibitory activity in lymphocyte cultures, probably due to the production of an array of immune inhibitory molecules [22]. Furthermore, the cytotoxic T cell-mediated responses are suppressed, both activated and memory $\mathrm{T}$ cells being selectively depleted in the testis, while $\mathrm{T}$ regulatory (Treg) cell responses are induced [59]. The population of testicular macrophages, even when they show a capacity to interact with activated $\mathrm{T}$ cells, display an impaired capacity to induce inflammation and lymphocyte activation [22]. Furthermore, sex steroid hormones such as testosterone and estradiol also modulate macrophage and lymphocyte activities in mammals. In mammals, the high levels of testosterone found within the testis might have immunosuppressive properties against macrophages and lymphocytes as there is evidence that this hormone inhibits the progression of autoimmune orchitis [60]. In contrast, $E_{2}$ seemed to trigger testicular inflammation in mammals and impaired the graft survival in the mammalian testis (see for review [21,22]).

The presence of leucocytes and the immune response regulation in the gonad have received little attention in fish, and most of the functional data accumulated to date on testicular leucocytes have been obtained in one species—-the gilthead seabream — by a single research group. Studies comparing testicular and head-kidney (the main hematopoietic organ in fish) acidophilic granulocytes demonstrated that this cell type is requisitioned by the testis at certain stages of the reproductive cycle, and once they infiltrate the organ, their functional activities are drastically suppressed [49]. Moreover, the presence of testicular cells in head-kidney acidophilic granulocyte cultures inhibits their phagocytic activity against bacteria [61]. As in mammals, gilthead seabream and European sea bass testis constitutively expresses many cytokines with an expression pattern that depends on the reproductive stage [51,62]. In addition, suppression of cytokine signaling (SOCS)- 1 and 3 , which act as a negative feedback of cytokine receptor signaling, has been described in the gonad of pufferfish (Tetraodon nigroviridis) [63,64]. Interestingly, androgens and estrogens also have an important regulatory role in the activity of both myeloid and lymphoid cell types in several fish species. In fact, the increasing amount of data about how sex steroid hormones and others such as gonadotrophin-release hormone, gonadotrophins, GH, or IGFs affects the immune cells of several fish species by acting on nuclear or membrane receptors clearly points to a communicative network between the immune and the neuro-endocrine system in fish (see for review [10-17]). As recent reviews have extensively 
described this influence, we have focused on the immune regulation and leucocyte functions within the reproductive tissues of fish, although fewer data are available.

As regards the testis, androgens are able to induce the recruitment of acidophilic granulocytes and immunoglobulin M (IgM)-producing B lymphocytes into the testis of gilthead seabream, as can estrogens [65-67]. However, and unlike estrogens, androgens down-regulate the expression of several TLR genes in the testis, inducing an immune-tolerance status $[67,68]$. In mammals, high levels of estradiol promote an increase in the amount of activated macrophages and mast cells in the testes, leading to inflammatory-dependent infertility [69]. However, in fish, the number of testicular macrophages remains steady at different reproductive stages and after estrogenic treatment $[62,65]$. Whether the effect of estrogens in fish represents an inflammatory process that can lead to infertility, as occurs in mammals, merits further research, as estrogens in fish up-regulate both pro- and anti-inflammatory cytokines and only seem to trigger a normal post-spawning stage $[65,66,69]$. All these data suggest that the immune privilege status of the testes in teleost fish might be similarly regulated to the mammalian equivalents, although differences reflecting their evolutionary status and their special testicular physiology and structure are evident. Greater knowledge of the regulation and establishment of the immune privilege in the fish gonad will contribute to the fight against very specialized pathogens (see below) that use the reproductive system to evade the immune response. Thus, the immune response in the gonad and its regulation is worthy of further investigation in fish in order to develop preventive and palliative treatments will be of use to the aquaculture sector.

\subsection{The Ovary Environment that Allows Immune Privilege}

Regarding the vertebrate ovary, the influx of leucocytes into the ovary is allowed through vascular and lymphatic vessels. Several types of resident leucocytes are also present in the ovary of mammals, where they are involved in ovulation and in the development of the corpus luteum (see for review [20]. In hen (Gallus gallus) ovaries, macrophages are present in the theca layer and are able to phagocytose particles, being the first line of defense of pre- and post-ovulatory follicles [70]. Moreover, follicular cells (both theca and granulose cells) express TLRs that induce an innate immune response, including the expression of several $\beta$-defensins, which are important AMPs [70]. The presence in the follicles of antigen-presenting cells and $\mathrm{T}$ and $\mathrm{B}$ lymphocytes is related with sexual maturation and probably with estrogen levels. Interestingly, these cells increase in number upon an infection [70]. Similarly, in the elasmobranch fish Little skate (Leucoraja erinacea) ovary, direct contact between leucocytes and the follicle wall as well as between the steroidogenic theca and granulosa cells has been demonstrated [71]. In the teleost fish gilthead seabream, acidophilic granulocytes appear in great numbers in the developing ovarian area during larval development, remaining until the area is totally developed [72], while in the adult gonad, they are restricted to the connective tissue that limits the testicular and ovarian areas and to the testicular interstitium [49].

\section{The Gonad Immune Responses in European Sea Bass-Preliminary Data}

The low capacity of the reproductive tissues to induce a highly inflammatory response against pathogens suggests a need for other immune responses in order to block infections. As mentioned above, fish gonads have variable amounts of immune cells, including macrophages, lymphocytes, granulocytes, and mast cells, even though their functioning is not well understood. While their presence and the expression of leucocyte markers, IFN pathway molecules, or cytokines have been described $[50,51,62,73]$, there has been very little in the way of a functional analysis of gonad cells in fish. Besides the molecules described above, AMPs-low weight peptides with amphipathic properties-that are up-regulated upon infection and display a broad-spectrum of antimicrobial functions are also present. Some of them have been described as regulating molecules of the innate immune response, but most of them seem to act without triggering an inflammatory response [74]. In the mammalian and avian reproductive tissues, several types of AMPs have been described, as in fish [75-79]. Thus, as described previously, two hepcidins have been detected in the testis of 
mudskipper, one of them (hepcidin-2) being regulated by gonadotrophins and stimulated by LPS [56]. In addition, a $\beta$-defensin in orange-spotted grouper is specifically expressed in pituitary and testis, though it shows a steady expression in the pituitary its expression in the gonad increased during sex reversal from female to male. This is produced by the Sertoli cells enclosing spermatogonia or primary spermatocytes but not other more developed germ cells [57]. Furthermore, this pituitary-testis specific $\beta$-defensin displays antibacterial and antiviral functions [57] leading to the hypothesis that this $\beta$-defensin might have a dual role in immune defense and paracrine/endocrine regulation. Taking all this into account, further studies based on the role of AMPs in the neuro-endocrine reproductive axis are necessary in order to identify the more effective immune response in reproductive tissues against specific pathogens and how these responses might affect reproduction. In what follows, we will present some preliminary data about the functional characterization of the main cellular innate immune functions of European sea bass ovary and testis cell suspensions and discuss whether fish gonads produce specific antimicrobial peptides.

\subsection{Cellular Innate Immune Functions}

Ovaries and testes from healthy adult European sea bass males and females were excised, and cell suspensions were obtained by forcing the fragments through a $100 \mu$ m nylon mesh using L-15 Leibovitz culture medium supplemented with antibiotics, $2 \mathrm{mM}$ glutamine, $0.5 \%$ gelatin, and $5 \%$ fetal bovine serum. Cells were washed, counted, and their viability was determined as being higher than $90 \%$. Ovary and testis cells were used to determine some of the main cellular innate immune functions using flow cytometric assays. Thus, the $\%$ of phagocytic cells and the mean intensity of fluorescence per cell was determined using fluorescein stained-yeast cells [80]. The $\%$ of cells producing reactive oxygen species (ROS), as well as the intensity of fluorescence reflecting the ROS level per cell, was determined after an incubation with dihydrorhodamine 1,2,3 and upon activation with phorbol myristate acetate [81]. Finally, the cell-mediated cytotoxic activity against xenogeneic tumor cells was determined as the $\%$ of tumor cells killed by cytotoxic cells [82]. All the techniques were applied as elsewhere with their respective negative controls to test the specificity.

The results show that phagocytosis, respiratory burst, and cell-mediated cytotoxic activities were detected in cellular suspensions from sea bass ovary or testis (Figure 1). In contrast to what happens in the case of respiratory burst, the percentage of phagocytosis and cell-mediated cytotoxicity activities were lower in the ovary than in the testis of European sea bass. Interestingly, ovary cell phagocytosis was significantly lower than that of the testis but the phagocytic ability, determined by the intensity of fluorescence, was slightly higher, which demonstrates that gonad cells have different cellular innate immune functions, although the cell types present and their exact function remain to be determined.

Unfortunately, there is very little in the literature in this respect. The first evidence was obtained in rainbow trout, where macrophages incubated with testis extracts showed an increased size and greater phagocytic activity but decreased chemotaxis [83]. In the most studied case, gilthead seabream testis cells showed very little-almost undetectable - phagocytic activity $(1-3 \%)$, while the percentage of ROS-producing cells (almost 40\%) and the ROS levels were quite high [61], the role of acidophilic granulocytes being dissected and relevant. Strikingly, the incubation of seabream head-kidney leucocytes with testicular cell medium reduced phagocyte functions, suggesting the production and release of inhibitory molecules by testicular cells that could be related to the special testicular regulation and microenvironment. In sharp contrast, in the viviparous fish okitango (Neoditrema ransonnetii), the incubation of leucocytes with ovary-conditioned medium resulted in unaltered phagocyte functions, while Concavalin A-induced lymphocyte proliferation was drastically impaired, which, at least partially, would be due to the presence of large amounts of prostaglandin $E_{2}$ [84]. However, all this might be also related to fish sex, age, season, and reproductive and hormonal status, and all these factors need to be treated cautiously when performing the experiments and comparing the data. 


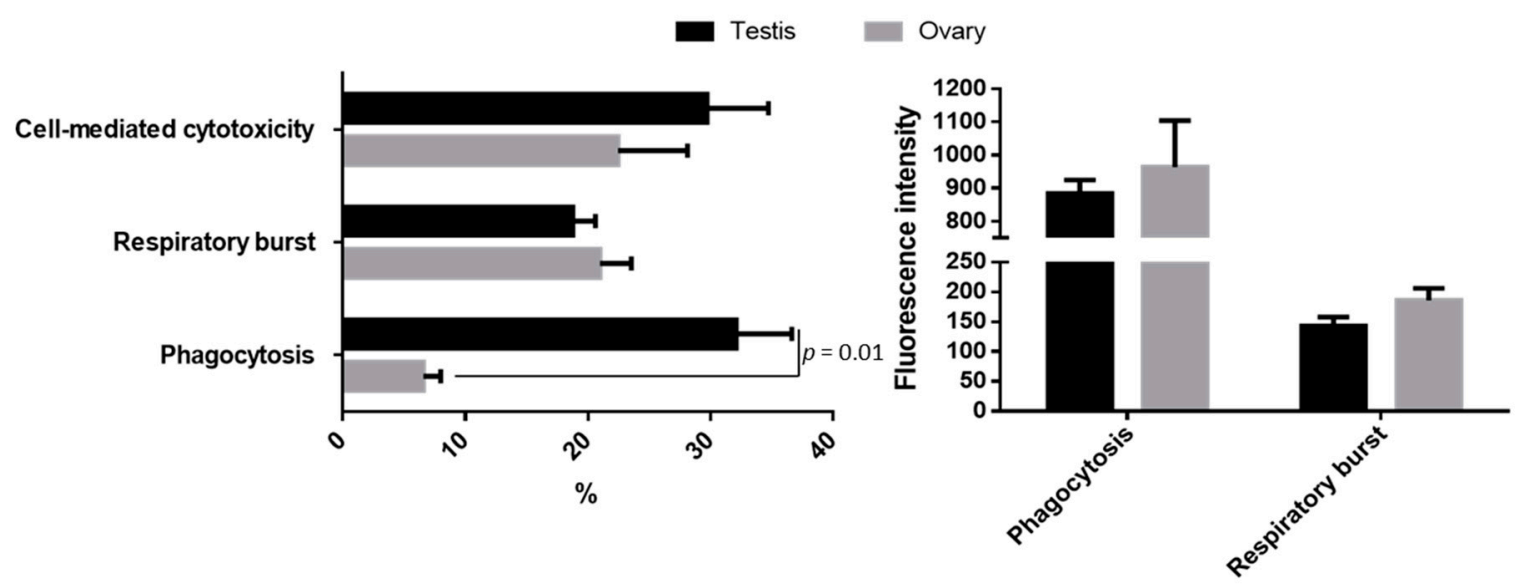

Figure 1. Cellular innate immune activities (phagocytosis, respiratory burst and cell-mediated cytotoxicity) of European sea bass testis and ovary cell suspensions determined by flow cytometry. Data represent the mean \pm standard error mean (SEM) $(n=6)$. Statistical analysis of the corresponding parameters between testis and ovary were determined by the $t$-Student test.

\subsection{Description of Antimicrobial Peptides}

The ovaries and testes from healthy adult European sea bass males and females (507 $\pm 56 \mathrm{~g}$ and $357 \pm 39 \mathrm{~g}$ body weight, respectively) were removed at spawning reproductive stage for AMPs isolation. Positive samples for antimicrobial activity, assayed against Micrococcus luteus, Escherichia coli, or Candida albicans, were used for the isolation of unknown antimicrobial peptides using the methodology previously described [85]. Briefly, ovaries and testes were homogenized in $10 \%$ acetic acid, ultra-centrifuged at 100,000 $\mathrm{g}$ for $3 \mathrm{~h}$ and the supernatants were recovered. Then, solid phase extraction was performed by means of Sep-Pak C $812 \mathrm{cc}$ Vac cartridges followed by reverse phase high-performance liquid chromatography (RP-HPLC) with a CapCell-Pak C18 column using a lineal gradient of acetonitrile (ACN). Peaks were then recovered and tested for antibacterial activity as described below. Positive fractions were re-purified and again subjected to antibacterial assays to confirm that the peptides from gonads were active. Most active fractions recovered were further eluted in a $20-50 \%$ gradient by reverse phase HPLC and analysed by matrix assisted laser desorption ionization-time of flight (MALDI-TOF) mass spectrometry. Samples were also processed for sodium dodecyl sulfate polyacrylamide gel electrophoresis (SDS-PAGE) separation of the proteins and stained with Coomassie blue.

For the antimicrobial activity, fish opportunistic and non-pathogenic bacteria, M. luteus and E. coli, respectively, and the fungus C. albicans were grown in agar plates at $37^{\circ} \mathrm{C}$ in tryptic soy agar (TSA). Then, fresh single colonies of 1-2 mm were diluted in $5 \mathrm{~mL}$ of tryptic soy broth (TSB), cultured for $16 \mathrm{~h}$ at their respective optimal temperatures on an orbital incubator at 200-250 rpm and adjusted to $10^{6} \mathrm{cfu}$. Aliquots of $30 \mu \mathrm{L}$ of each of the bacterial dilutions $(1 / 10)$ were placed in flat-bottomed 96-well plates and cultured with equal volumes of serially diluted European sea bass gonad samples. Antimicrobial activity was evidenced by the observation of no turbidity in the well after $24 \mathrm{~h}$ of incubation. Samples without microbial activity were used as blanks (negative control), and samples without sample were used as positive controls ( $100 \%$ growth or $0 \%$ activity).

The SDS-PAGE results pointed to different protein profiles between the male and female gonads of European sea bass adult specimens, although in both cases the bands were lower than $14 \mathrm{kDa}$ (Figure 2a), which reflects the low size of AMPs. Interestingly, males presented higher amounts of low weight proteins than females but both male and female gonad whole extracts had antibacterial activity against $M$. luteus (Table 1). After solid phase extraction, only the $40 \% \mathrm{ACN}$ fraction was positive in both sexes (Table 1), which underwent to RP-HPLC showing completely different protein profiles between the fractions from gonads of males and females (Figure 2b), coinciding with the results observed in 
SDS-PAGE gels (Figure 2a). Then, the antibacterial activity was tested with all the different fractions obtained, resulting in two different positive regions in males and females (Figure $2 b$ ). The peaks corresponding to region 1 eluted at $23 \% \mathrm{ACN}$ in males and at $32 \% \mathrm{ACN}$ in females, while the peaks of region 2 eluted at a similar ACN percentage in both sexes (Figure 2b). However, in female gonads only one peptide of low weight $(5.5 \mathrm{kDa})$, was found in region 1 , as observed using an SDS-PAGE gel (Figure 2c), while in male gonads both regions 1 and 2 contained low molecular weight peptides (of about 6 and $2 \mathrm{kDa}$, in regions 1 and 2 respectively). Region 2 of the testis was observed to develop the highest antibacterial activity, so this was re-purified, and antimicrobial activity against M. luteus was confirmed (Figure $2 \mathrm{~d}$ and Table 1 ). In this region, a single peptide was found with a weight of $3.316 \mathrm{kDa}$ according to RP-HPLC and MALDI-TOF mass spectrometry (Figure 2d,e). Unfortunately, this peak has not been unequivocally identified in the fish or European sea bass databases.

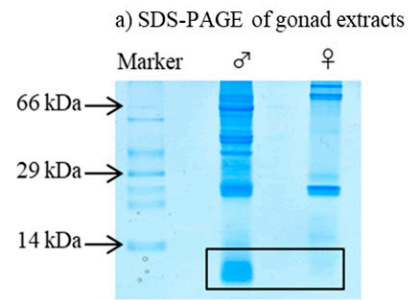

b) RP-HPLC of European sea bass gonads
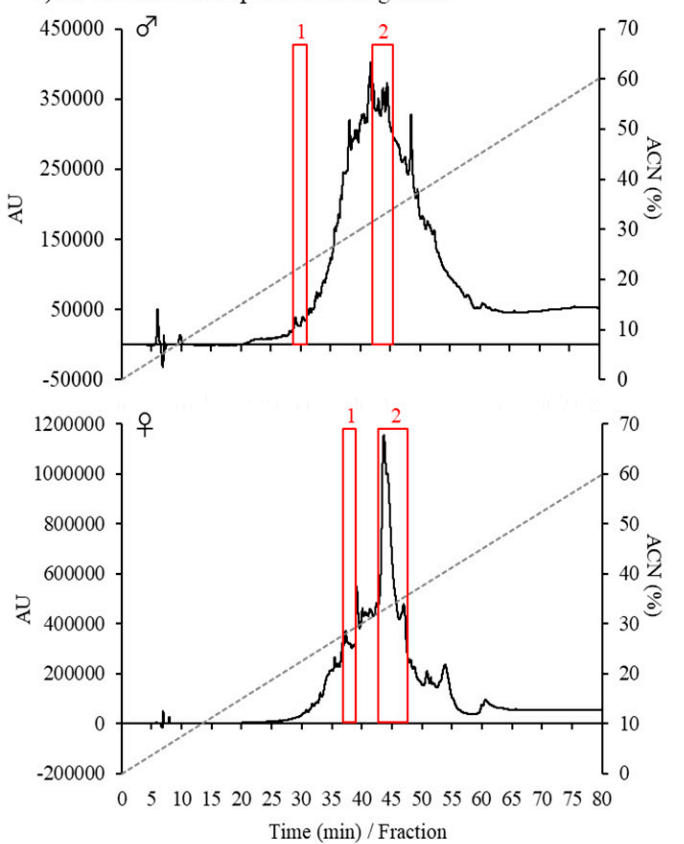

Time (min) / Fraction

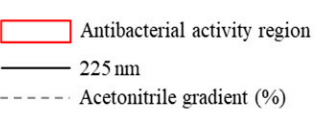

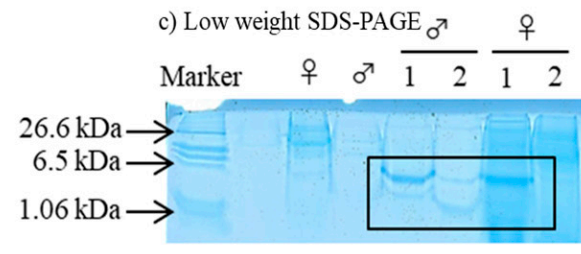

d) RP-HPLC of peak 2 from males

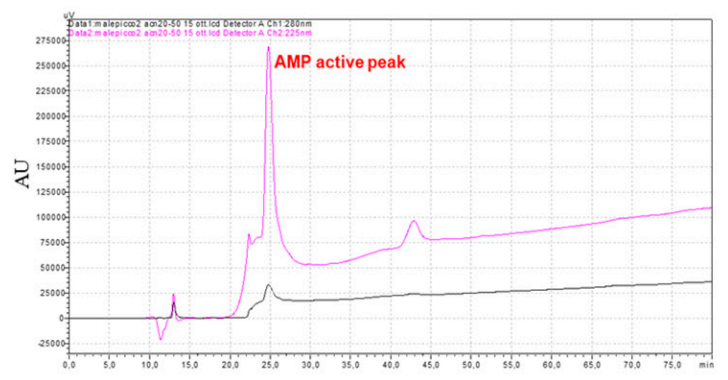

e) MALDI-TOF mass spectrum of peak 2 from males

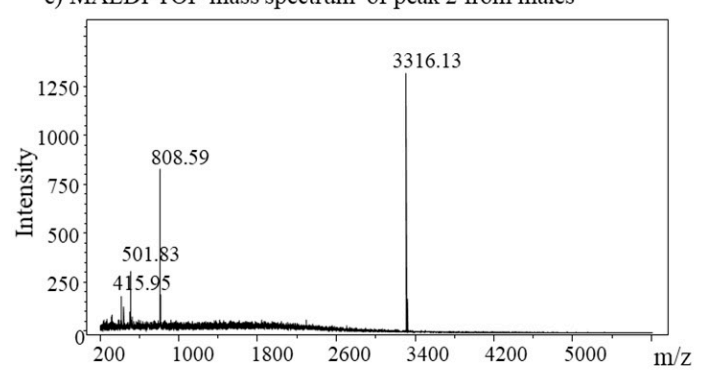

Figure 2. Determination of antimicrobial peptides (AMPs) from adult European sea bass gonads. (a) for sodium dodecyl sulfate polyacrylamide gel electrophoresis (SDS-PAGE) of whole testis and ovary homogenates. (b) Peptidic profile of testis and ovary by reverse phase high-performance liquid chromatography (RP-HPLC) and bactericidal activity. (c) Low weight SDS-PAGE of ovary and testis homogenates and peptides purified by RP-HPLC with antibacterial activity. (d) Peak 2 of testis purified by RP-HPLC with antibacterial activity. (e) Matrix assisted laser desorption ionization-time of flight (MALDI-TOF) mass spectrometry mass spectrum of peak 2 of testis. Black squares: region of interest; red squares: region with antibacterial function; $\sigma^{7}$ : male; of: female; ACN: acetonitrile; AU: absorption units. 
Table 1. Antimicrobial activity against Micrococcus luteus, Escherichia coli, or Candida albicans in ovary or testis from adult European sea bass healthy specimens. Lowest serial dilution of samples with antimicrobial activity is shown. RP-HPLC, reverse phase high-performance liquid chromatography; ACN, acetonitrile; middle script (-), non-detected activity; ND, not determined. To see equivalence of regions, see Figure 2.

\begin{tabular}{|c|c|c|c|c|c|}
\hline Time Tested & Sex & Region & Micrococcus luteus & Escherichia coli & Candida albicans \\
\hline \multirow[t]{2}{*}{ Naïve } & Testis & Complete & $1: 2$ & - & - \\
\hline & Ovary & Complete & $1: 2$ & - & - \\
\hline \multirow[t]{6}{*}{ After Sep-Pak purification } & Testis & $10 \% \mathrm{ACN}$ & - & - & - \\
\hline & & $40 \% \mathrm{ACN}$ & $1: 64$ & $1: 8$ & $1: 4$ \\
\hline & & $80 \%$ ACN & - & - & - \\
\hline & Ovary & $10 \% \mathrm{ACN}$ & - & - & - \\
\hline & & $40 \% \mathrm{ACN}$ & $1: 32$ & $1: 2$ & - \\
\hline & & $80 \%$ ACN & - & - & - \\
\hline \multirow[t]{4}{*}{ After 1st RP-HPLC purification } & Testis & Region 1 & $1: 8$ & ND & ND \\
\hline & & Region 2 & $1: 16$ & ND & ND \\
\hline & Ovary & Region 1 & $1: 4$ & ND & ND \\
\hline & & Region 2 & $1: 16$ & ND & ND \\
\hline \multirow[t]{4}{*}{ After 2nd RP-HPLC purification } & Testis & Region 1 & - & ND & ND \\
\hline & & Region 2 & $1: 1$ & ND & ND \\
\hline & Ovary & Region 1 & - & ND & ND \\
\hline & & Region 2 & - & ND & ND \\
\hline
\end{tabular}

The production of specific AMPs has been related with several reproductive issues. For example, it has been suggested that the reproductive tract of mudskipper synthesizes specific antimicrobial compounds to clean fertilized eggs before hatching and that Hepcidin-1 and Hepcidin-2 play a key role in pathogen clearance during the reproductive process [56]. In hermaphroditic orange spotted grouper, beta-defensin isolated from pituitary is mainly expressed in testis [57]. Furthermore, using proteomic approaches, a specific protein from testis, ovary, and brain with antimicrobial activity was identified (IQ motif containing H (IQCH protein)) and found to be greatly stimulated after bacterial infection with Edwardsiella tarda, afterward appearing in serum and binding to bacteria [86]. All these data highlight the role of antimicrobial peptides in the reproductive organs of fish and to the need for further characterization of this activity in the reproductive tract of fish in order to determine potential therapies in the fight against gonad-colonizing pathogens without disturbing the reproductive process.

\section{Infection of the Gonad as a Perfect Way to Evade the Immune Response in Fish}

The special immune conditions provided by the gonads seem to be ideal for pathogens to colonize and evade the systemic immune response. In vertebrates, pathogens that generally spread through the gonad efficiently infect this tissue. For example, in humans, despite the presence of the blood-testis barrier, several viruses are able to overcome this limitation and infiltrate the germinal epithelium, thus developing persistent infections [23]. Several pathogens infect the ovary of vertebrates, inducing ovarian pathologies that lead to infertility. As mammalian pathogens are transplacental and transferred through breastfeeding, the transovarian pathway seems not to be highly relevant (see for review [87-90]). In birds, as in fish, however, gonadal infection of both sexes is used to evade the immune system and also to assist transmission to the next generation [91-95]. As regards fish, several pathogens have been found to infect gonads in a few species (see Table 2).

Regarding parasite infections in fish, the little information available suggest that parasites do not to use the germ cells to be transmitted but produce infertility. In European sea bass, there is a coelozoic parasite, Sphaerospora testicularis, that colonizes the seminiferous tubules of the testes, causing myxosporoses [96-98]. Parasitation with S. testicularis provokes an influx of leucocyte, mainly macrophages, granulocytes, lymphocytes, and plasmacytes [99], leading to the complete destruction of testis tissue and greatly reducing fish fertility [97-99]. 
In the case of bacterial infection, both Brucella pinnipedialis and Flavobacterium psychrophilum have been detected in the ovary of different species of fish (Table 2). Brucella spp. is the causative agent of brucellosis in mammals, a zoonosis widely distributed throughout the world [100]. Regarding fish, the Atlantic cod (Gadus morhua) was infected with B. pinnipedialis isolated from a wild hooded seal. Its extensive colonization of fish tissues, including the ovary, suggested that the fish could act as a transmission vector to wild seals [101]. In the case of bacterial cold-water disease (BCWD), it is produced by F. psychrophilum infection and has been seen to affect gametes of four different salmon species [102]. This bacterium has been described in testicular and ovarian fluid and inside the eggs of some species but not of others, which suggests that vertical transmission might be species-dependent [102-106].

The largest group of pathogens that colonize the gonad are viruses (Table 2). Although their detection in fish gonads is not a direct correlative factor, such transmission has been demonstrated in several cases. Indeed, viruses such as viral hemorrhagic septicemia virus (VHSV) and infectious pancreatic necrotic virus (IPNV) have been detected in gonadal fluids and/or gametes of several fish species. As regards VHSV, it was located in the ovary and ovarian fluids and was seen to replicate in the epithelium of the efferent ducts and in testicular interstitial cells $[93,107]$. Furthermore, the presence of VHSV genotype IVb in the gonad of different fish species of the Great Lakes has been confirmed using in situ hybridization techniques [108]. Besides the extensive presence of VHSV in the gonads of these species (including both somatic and germ cells), no damage was found either in ovary or testis of the fish species analysed [108]. Unlike VHSV, neither protein nor viral RNA of IPNV has been detected in rainbow trout ovaries, but IPNV infective particles were isolated from ovarian fluid cells and in the ovary of immature females previously infected, suggesting that IPNV can colonize the ovary and display a silent infection while not replicating in the organ $[95,107]$. These differences found in the behavior of both viruses in the gonad of rainbow trout were correlated with the immune response triggered by them. Thus, VHSV sharply up-regulated interferon coding genes in vivo, while IPNV failed to do so or elicited a marked down-regulations in the immune molecules [107]. In fact, IPNV is a widely known vertically transmitted virus [109], while there is no firm evidences of this mode of transmission in the case of VHSV [110].

For its part, spring viremia of carp virus (SVCV) is the pathogen responsible for the highly infectious spring viremia in many cyprinids, which produces serious injury of tissues in the kidney, spleen, and liver [119]. Moreover, it has been demonstrated that SVCV is able to infect grass carp ovary cells through both dependent- and independent-caveola endocytosis $[116,120]$. However, SVCV vertical transmission has not been demonstrated to date [110]. As with SVCV, the route of entry into the cells of the infectious spleen and kidney necrosis virus (ISKNV) is clathrin-mediated endocytosis via the caveolae [121]. Very recently, the presence of ISKNV was located in the ovarian follicle cells, but not in oocytes, of farmed Nile tilapia by the in situ hydroxynapthol blue-loop-mediated isothermal amplification (LAMP) assay [117]. However, vertical transmission of ISKNV has been reported in tilapia, using an in vitro fertilization experiment, which confirmed that the virus passed through ovarian fluids to the next generation during spawning [117]. Moreover, other studies performed in white sturgeon (Acipenser transmontanus) confirmed the transmission of ISKNV from adults to their progeny, though whether this occurred in the fluids or within the gametes remains unknown [122,123]. On the other hand, some fish viruses have not been detected in any reproductive organ or cell but are still thought to be transmitted vertically since they have been found in embryos or gonadal fluids. An example is the infectious salmon anemia virus (ISAV), which was not detected in Atlantic salmon (Salmo salar) gonads but was detected in ovarian fluids and eggs [124,125]. 
Table 2. Etiological agents reported to infect ovarian or testicular cells of several fish species. $\mathrm{NNV}$, nodavirus; VHSV, viral hemorrhagic septicemia virus; IPNV, infectious pancreatic necrotic virus; SVCV, spring viremia of carp virus; ISKNV, infectious spleen and kidney necrosis virus; $\mathrm{CCV}$, channel catfish virus; $\mathrm{qPCR}$, real-time PCR; RTG, rainbow trout gonad; $\mathrm{CO}$, grass carp ovary; $\mathrm{CCO}$, channel catfish ovary; ND, not determined.

\begin{tabular}{|c|c|c|c|c|c|}
\hline Etiological Agent & Fish Species & Tissue & Location & Detection Method & Reference \\
\hline \multicolumn{6}{|l|}{ Parasites } \\
\hline $\begin{array}{l}\text { Sphaerospora } \\
\text { testicularis }\end{array}$ & $\begin{array}{l}\text { European sea bass } \\
\text { (Dicentrarchus labrax) }\end{array}$ & Testis & $\begin{array}{c}\text { Extracellular: } \\
\text { Interstitial and } \\
\text { seminiferous tubules }\end{array}$ & $\begin{array}{l}\text { Transmission electron } \\
\text { and light microscopy }\end{array}$ & {$[96,111]$} \\
\hline \multicolumn{6}{|l|}{ Bacteria } \\
\hline $\begin{array}{c}\text { Brucella } \\
\text { pinnipedialis }\end{array}$ & $\begin{array}{l}\text { Atlantic cod } \\
\text { (Gadus morhua) }\end{array}$ & Ovary & ND & Bacterial growth culture & [101] \\
\hline \multirow{5}{*}{$\begin{array}{l}\text { Flavobacterium } \\
\text { psychrophilum }\end{array}$} & $\begin{array}{c}\text { Coho salmon } \\
\text { (Oncorhynchus } \\
\text { kisutch) }\end{array}$ & Ovary & Gametes & Conventional PCR & \multirow{4}{*}{ [102] } \\
\hline & $\begin{array}{l}\text { Chinook salmon } \\
\text { (Oncorhynchus } \\
\text { tshawytscha) }\end{array}$ & Ovary & Gametes & Conventional PCR & \\
\hline & $\begin{array}{c}\text { Shum salmon } \\
\text { (Oncorhynchus keta) }\end{array}$ & Ovary & Gametes & Conventional PCR & \\
\hline & $\begin{array}{c}\text { Rainbow trout } \\
\text { (Oncorhynchus } \\
\text { mykiss) }\end{array}$ & Ovary & Gametes & Conventional PCR & \\
\hline & $\begin{array}{l}\text { Baltic salmon } \\
\text { (Salmo salar) }\end{array}$ & Ovary & Gametes & Bacterial growth culture & [104] \\
\hline \multicolumn{6}{|l|}{ Virus } \\
\hline \multirow{9}{*}{ NNV } & $\begin{array}{l}\text { Pacific cod (Gadus } \\
\text { macrocephalus) }\end{array}$ & Gonad & ND & qPCR & [112] \\
\hline & \multirow[t]{3}{*}{ European sea bass } & Testis & Sertoli & $\begin{array}{l}\text { in situ PCR and } \\
\text { re-isolation in cell } \\
\text { culture }\end{array}$ & [113] \\
\hline & & & Sperm & Conventional PCR & \multirow{2}{*}{ [114] } \\
\hline & & Ovary & ND & Conventional PCR & \\
\hline & \multirow{2}{*}{$\begin{array}{l}\text { Shi drum } \\
\text { (Umbrina cirrosa) }\end{array}$} & Testis & Sperm & Conventional PCR & \multirow{2}{*}{ [114] } \\
\hline & & Ovary & ND & Conventional PCR & \\
\hline & $\begin{array}{l}\text { Gilthead seabream } \\
\text { (Sparus aurata) }\end{array}$ & Testis & $\begin{array}{l}\text { Tunica albuginea, } \\
\text { Sertoli and germ } \\
\text { cells Tunica } \\
\text { albuginea Germ cells }\end{array}$ & $\begin{array}{c}\text { in situ PCR, } \\
\text { immunohistochemistry } \\
\text { and re-isolation in cell } \\
\text { culture }\end{array}$ & [113] \\
\hline & \multirow{2}{*}{$\begin{array}{c}\text { Striped jack } \\
\text { (Pseudocaranx } \\
\text { dentex })\end{array}$} & Ovary & ND & Conventional PCR & \multirow{2}{*}{ [115] } \\
\hline & & Testis & ND & Conventional PCR & \\
\hline VHSV & Rainbow trout & Ovary & $\begin{array}{l}\text { Efferent duct's } \\
\text { epithelial and } \\
\text { interstitial cells }\end{array}$ & $\begin{array}{c}\mathrm{qPCR} \text { and } \\
\text { immunohistochemistry }\end{array}$ & [108] \\
\hline IPNV & Rainbow trout & Ovary & RTG-2 cell line & Ovarian cell line & [107] \\
\hline SVCV & $\begin{array}{c}\text { Grass carp } \\
\text { (Ctenopharyngodon } \\
\text { idella) }\end{array}$ & Ovary & CO cell line & Grass carp ovary cell line & [116] \\
\hline ISKNV & $\begin{array}{l}\text { Nile tilapia } \\
\text { (Oreochromis } \\
\text { niloticus) }\end{array}$ & Ovary & Follicle cells & $\begin{array}{l}\text { in situ hydroxynapthol } \\
\text { blue-loop-mediated } \\
\text { isothermal amplification }\end{array}$ & [117] \\
\hline $\mathrm{CCV}$ & $\begin{array}{l}\text { Channel catfish } \\
\text { (Ictalurus punctatus) }\end{array}$ & Ovary & CCO cell line & Ovarian cell line & [118] \\
\hline
\end{tabular}

\section{Nodavirus as a Viral Model to Unravel Fish Immuno-Endocrine Interactions}

As with all the previously described viruses, NNV colonizes fish gonads (Table 2) but also influences the endocrine and reproductive physiology of infected fish. This behavior, together with the high number of species that it is able to infect, makes NNV a good model to study immune-endocrine 
interactions in fish [126]. Nodavirus has been detected in the male and female gonad of several species in different reproductive stages, including European sea bass, gilthead seabream, Pacific cod (Gadus microcephalus), shi drum (Umbrina cirrosa), and striped jack (Pseudocaranx dentex) [112-115]. The cellular localization of the virus in the male gonad has recently been reported for the first time [113]. Thus, the gene coding for the capsid protein of NNV was located in Sertoli cells of European sea bass and gilthead seabream, and also in tunica albuginea and germ cells of gilthead seabream testis. Those data suggested that NNV can be vertically transmitted to the offspring through the germ cells or gonadal fluids in both species [113]. Although infective particles of NNV were recovered from the testes of both species, only in the testes of gilthead seabream were viral proteins (the capsid and B2 protein) detected by immunohistochemistry techniques [113]. Several studies about the transmission mechanisms of NNV point to both horizontal and vertical transmission modes [92,94,127-131]. Furthermore, in orange-spotted grouper, NNV was detected into the embryos, in which the virus continues replicating during the early stages of development, demonstrating that it is able to be vertically transmitted [130].

Gilthead seabream is an asymptomatic carrier of the traditional strains of NNV and does not suffer signs of infection or mortalities when it is infected with NNV (RGNNV genotype) [113,132]. However, European sea bass is an especially susceptible species to this virus and is known to suffer mortalities of up to 100\%, mainly in larvae and juveniles stages [127], which exhibit the typical signs of infection $[113,132,133]$. Taking all this into account, we have used these two species to reveal the behavior of NNV in the gonad and to discover whether the virus might take advantage of the alterations that occur in the immune and reproductive systems upon infection. It was found that the immune response triggered by NNV in the testis of both species is completely different both in brain, the target tissue for NNV, and immune tissues themselves. Thus, the testis of the European sea bass showed strong up-regulation of genes coding for pro-inflammatory cytokines, immunoglobulin $\mathrm{M}$, type I IFN pathway molecules (including sensors, intermediaries and effectors), AMPs (including defensin, hepcidin, lysozyme or histones), and acute-phase proteins such as haptoglobin, while their transcription was mainly unaltered or down-regulated in the brain $[75,113,134-136]$. Furthermore, some antimicrobial peptides seem to be locally regulated by the gonad since their pattern of expression coincides after in vivo and in vitro infection with NNV [75]. By contrast, in the gilthead seabream most immune-related genes were down-regulated in testis upon in vivo and in vitro infection but greatly up-regulated in the brain $[75,113,134,135]$.

Although the immune-reproductive interaction in fish has been studied for several decades, our knowledge of how pathogens profit from this complex interrelationship is still scarce. Our data showed that NNV modifies the sex hormonal status in juvenile males of European sea bass and gilthead seabream, although the modification observed was dependent on the species and associated with the different degrees of susceptibility the virus of both species [113]. Thus, in European sea bass, the $E_{2}$ levels decreased in the serum of infected specimens as the infection proceeded [113], whereas in gilthead seabream, the $\mathrm{E}_{2}$ serum levels increased from day 1 post-infection. On the other hand, 11-ketotestosterone (11KT) decreased at the beginning of the infection in both species [113]. The pattern of estrogens and androgens observed in European sea bass resembles the pattern found in other infections reported in very susceptible fish species. Thus, silver seabream specimens undergoing a vibriosis outbreak showed gradually increasing testosterone serum levels, whereas serum estradiol levels significantly decreased early upon infection and remained low until death [8].

The reproductive system is regulated by the brain-pituitary-gonad (BPG) axis which is known to share a complex set of molecules with the immune system such as signaling proteins and receptors (see for review [15,137]). In addition to altering sex hormone levels, NNV also seemed to alter the sensitivity of brain and testis to estrogens, modifying the expression levels of nuclear estrogen receptor (ER)-coding genes [113]. Our data showed that NNV modulates the gene expression of genes coding for molecules involved in estrogen signaling and production in the gonad but also in the brain in both species. Thus, in European sea bass testis the ER beta-coding genes (erb1-2) were up-regulated whilst 
in brain they were down regulated, as was neural aromatase coding gene (cyp19a2) [113]. By contrast, in gilthead seabream gonad, all estrogen receptor genes (era, erb1 and erb2) were down-regulated, while the gonadal aromatase coding gene (cyp19a1a) was up-regulated, as was era gene expression in the brain [113].

The fact that estrogen signaling and production was differently affected in both species, together with the fact that both species showed differences in susceptibility and immune responses upon NNV infection, prompted us to wonder whether the modification observed on the gene expression levels of several immune response molecules and estrogen receptors were statistically related and could have any physiological relevance. For this reason, we performed non-parametric Pearson correlation tests with the data obtained in in vivo infections and reported previously $[75,113,135]$. A statistically significant correlation was indeed found between the gene expression of sensors, intermediates and effectors of the type I IFN pathway and the erb2 gene in the NNV infected-testis of European sea bass and era gene in the infected-testis of gilthead seabream (Table 3). As regards AMPs, a positive correlation between the expression of era gene and several genes encoding for antimicrobial peptides in the gonad of gilthead seabream was also observed (Table 4).

Table 3. Correlations observed between the gene expression of erb2 in European sea bass or era in gilthead seabream testis and interferon (IFN)-related genes after in vivo infection with NNV. The first line corresponds to the Pearson coefficient of correlation and the second to the $p$ value. Written in bold are the correlated parameters. mda5, melanoma differentiation-associated gene 5; lgp2, laboratory of genetics and physiology 2; mavs, mitochondrial antiviral signaling; traf3, tumor necrosis factor (TNF) receptor-associated factor 3; tank, TRAF3, family member-associated NF-kB activator 3; tbk1, TANK-binding kinase 1 ; irf, IFN regulatory factor; $m x$, myxovirus (influenza) resistance protein; $p k r$, dsRNA-dependent protein kinase receptor; $e r$, estrogen receptor.

\begin{tabular}{cccccccccccc}
\hline & mda5 & lgp2 & mavs & traf3 & tank & tbk1 & irf3 & irf7 & ifn & mx & pkr \\
\hline \multirow{2}{*}{ Sea bass erb2 } & - & 0.73 & 0.58 & $\mathbf{0 . 6 0}$ & 0.46 & $\mathbf{0 . 6 9}$ & $\mathbf{0 . 6 9}$ & $\mathbf{0 . 5 9}$ & $\mathbf{0 . 6 7}$ & $\mathbf{0 . 7 5}$ & 0.67 \\
& - & $\mathbf{0 . 0 0}$ & $\mathbf{0 . 0 2}$ & $\mathbf{0 . 0 1}$ & 0.07 & $\mathbf{0 . 0 0}$ & $\mathbf{0 . 0 0}$ & $\mathbf{0 . 0 1}$ & $\mathbf{0 . 0 0}$ & $\mathbf{0 . 0 1}$ & 0.00 \\
\hline \multirow{2}{*}{ Gilthead seabream era } & $\mathbf{0 . 8 9}$ & - & - & - & - & $\mathbf{0 . 7 7}$ & $\mathbf{0 . 8 0}$ & - & $\mathbf{0 . 8 8}$ & $\mathbf{0 . 8 2}$ & 0.82 \\
& $\mathbf{0 . 0 0}$ & - & - & - & - & $\mathbf{0 . 0 0}$ & $\mathbf{0 . 0 0}$ & - & $\mathbf{0 . 0 0}$ & $\mathbf{0 . 0 0}$ & 0.00 \\
\hline
\end{tabular}

Table 4. Correlations observed between the gene expression of era gene and several AMP-coding genes in gilthead seabream testis after in vivo infection with NNV. The first line corresponds to Pearson coefficient of correlation and the second to the $p$ value. Written in bolds are the parameters correlated. c3, complement component 3; lyz, lysozyme; hamp, hepcidin; bdef, $\beta$-defensin; pis, piscidin; $h 1$, histone 1 ; $h 2 b$, histone $2 \mathrm{~B}$; era, estrogen receptor a.

\begin{tabular}{cccccccc}
\hline & c3 & lyz & hamp & bdef & pis & h1 & h2b \\
\hline Gilthead & 0.79 & 0.67 & 0.42 & 0.85 & 0.88 & 0.77 & 0.79 \\
seabream era & $\mathbf{0 . 0 0}$ & $\mathbf{0 . 0 0}$ & $\mathbf{0 . 0 4}$ & $\mathbf{0 . 0 0}$ & $\mathbf{0 . 0 0}$ & $\mathbf{0 . 0 0}$ & $\mathbf{0 . 0 0}$ \\
\hline
\end{tabular}

Interestingly, ER activity has been shown to modulate innate immune signaling pathways in dendritic cells and macrophages in humans and fish [138-141]. The positive correlation observed between ERs and several molecules of the IFN pathway suggested that the modulation of the expression of ERs, together with the changes observed in the $E_{2}$ serum levels influence the ability of the immune system to react upon NNV infection. Similarly, the activation of ER $\alpha$ by physiological adult levels of $\mathrm{E}_{2}$ promotes the production of type I IFN in mammals [139]. It is of note that antibacterial functions in er $2 b$ mutant zebrafish (Danio rerio) seemed not be affected, while antiviral functions were impaired during SVCV infections [142].

Regarding gilthead seabream, high levels of estrogenic compound in serum triggered a post-spawning season and the infiltration of several types of leucocytes into the testis $[65,66]$. However, and even though $\mathrm{E}_{2}$ serum levels increased upon NNV infection, the down-regulation of estrogen 
receptors observed in the testis was sufficient to avoid the estrogen-dependent inflammatory effect and the up-regulation of the immune response based on IFN pathways and antimicrobial peptides, thus allowing normal testicular functionality during the infection and, in turn, allowing the virus to spread. In European sea bass, however, their great susceptibility to infection and the high levels of NNV found in those specimens seem to lead to the activation of the immune response in all tissues, including the testis. Thus, the up-regulation of the erb2 gene observed will tend to up-regulate the induction of IFN pathway. Interestingly, an though the functionality of the testis is not a priority for moribund fish, no alteration of the testicular morphology of infected fish was observed [113].

In order to be transmitted through the gonad, the production of gametes has to be induced or at least not blocked. Bearing this in mind we also analysed the expression of several genes of the kiss peptide signaling pathway in the brain of European sea bass, the most susceptible species, using the samples obtained in previous infection experiments [113]. This pathway has been described in all vertebrate groups as being an essential upstream regulatory element of the BPG axis which regulates reproduction. The kisspeptins pathway activation is involved in the release of gonadotropin-releasing hormone $(\mathrm{GnRH})$ in the brain, which is subsequently involved in the release of the gonadotropin hormones (luteinizing and follicle-stimulating hormones) in the pituitary, and, in turn, acts in the regulation of the steroidogenesis and gametogenesis in the gonad (see for review [143]). In European sea bass, two forms of kisspeptin genes-kisspeptin 1 (kiss1) and kisspeptin 2 (kiss2) - have been described, as have two forms of G-coupled protein receptor for kisspeptins-gpr54-1b and gpr54-2b-all of them with a role in the seasonal control of reproduction $[144,145]$. We analysed the gene expression patterns of the two kisspeptins (kiss1 and kiss2; acc. numbers FJ008914 and FJ008915, respectively), two G-protein coupled receptors (gpr541b and gpr542b; acc. numbers FJ202446 and FJ202447, respectively), and three gonadotrophin-releasing hormones (gnrh1, gnrh2, and gnrh3; acc. numbers AF224279, AF224281, and AF224280, respectively) by real-time PCR [135].

After NNV infection, several coding genes involved in the kisspeptin pathway were affected (Figure 3) but not others (data not shown). Thus, NNV increased the expression of kiss2 in the brain of infected animals 7 days after infection (Figure 3a), while the expression of one receptor, the $g n r 541 b$ was completely blocked at all time points assayed (Figure 3b). By contrast, only gnrh1 transcription was affected, showing an increase in its expression 1 and 7 days after infection (Figure 3c). This virus is known to decrease $\mathrm{E}_{2}$ and $11 \mathrm{KT}$ serum levels concomitantly with the down-regulation of the expression levels of some estrogen receptors in the brain and neural aromatase gene expression [113]. Our data also pointed to the blockage of a kiss peptide receptor gene expression (gpr541b) at all time points during the infection. Whether this effect is due to cell death induced by NNV infection or whether gpr541b-expressing neurons are more susceptible to NNV infection than others needs further study. However, increasing levels of kiss2 and gnrh1 expression were also observed at day 7 of infection. Recently, a study performed in European sea bass related the gene-expressing levels of the kisspeptin pathway genes with seasonal reproductive stages and gonadal functions [144], suggesting that the alterations observed in this pathway upon infection might affect the reproduction capabilities of the specimens. Our data do not support the idea that NNV triggered the production of gametes, but it is clear that NNV infection modifies several reproductive parameters in brain and gonad. Whether or not this influences the efficiency of reproduction in asymptomatic species or in surviving specimens also deserves to be studied in greater depth. 

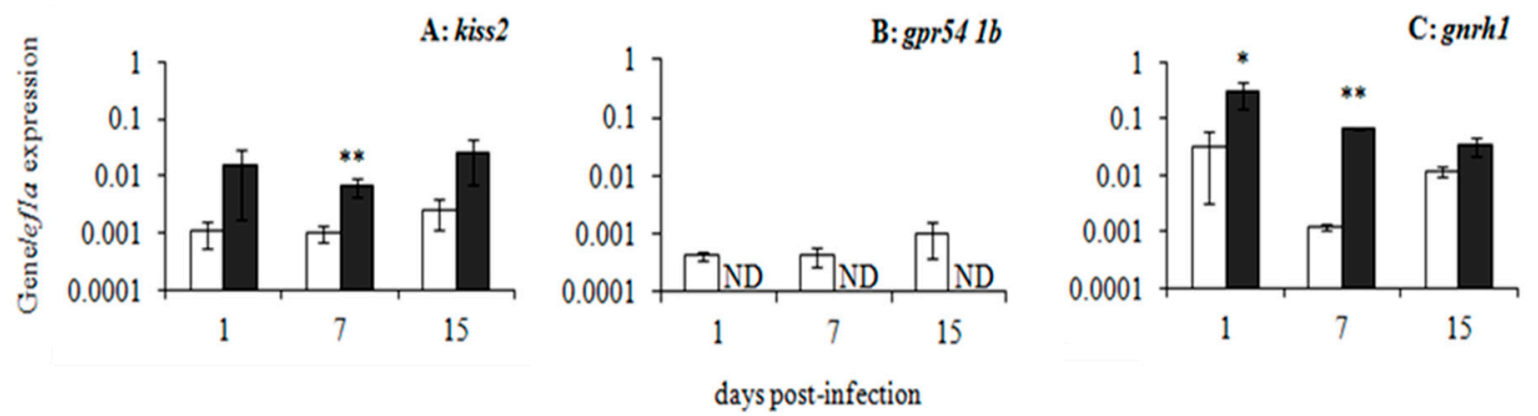

Figure 3. Expression of kisspeptin regulation route genes (A) kiss2, (B) gpr541b, and (C) gnrh1 upon NNV infection in vivo in European sea bass brain. Control group was intramuscularly injected with $0.01 \mathrm{M}$ PBS (white bars) and NNV group with $10^{6} \mathrm{TCID}_{50} \mathrm{NNV} /$ fish (black bars). Bars represent the mean $\pm \operatorname{SEM}(n=6)$. Asterisks denote statistical differences between groups $\left({ }^{*} p<0.05 ;{ }^{* *} p<0.01\right)$. ND, undetected.

\section{Conclusions}

This review has focused on the special immune characteristics and regulation of the fish gonad and the ability of some pathogens to colonize this organ and how they elude both systemic and local immune responses to survive and spread. We first described how gonad immunity manifests itself and presented some preliminary data about the cellular innate immune functions present in both testis and ovary from the European sea bass, as well as the presence of antibacterial and antifungal activities, probably due to the existence of specific locally produced AMPs, since one small peptide with antibacterial activity was isolated from the testis. Interestingly, both gonad structure and sex hormones have relevant roles upon local infection in the fish gonad. These infections are produced mainly by a wide range of viruses, although there are also several bacteria and parasites able to hide in the tissue, sometimes giving rise to a severe degree of infertility. For its part, NNV is a virus that colonizes the testis of European sea bass and gilthead seabream, altering the immune response of the gonad itself, triggering changes in serum levels of androgens and estrogens, and affecting the expression pattern of kisspeptins in the brain. All these data, together with the correlations between ERs and immune-related gene expression, suggest that NNV alters the immune-endocrine interaction in the host. The evidence suggests that pathogens influence immune-endocrine regulation and gonad physiology to produce a more efficient infection for their transmission. Whatever the case, it is clear that further research is needed to develop new strategies to prevent or at least attenuate the vertical spread of pathogens.

Author Contributions: Y.V., E.C.-P., M.C., and A.C. analysed the samples and the data; Y.V. and E.C.-P. wrote the manuscript; E.C.-P., A.C., and M.A.E. conceived the manuscript and funded the work.

Funding: Work partly funded with grants AGL2013-43588-P and AGL2016-74866-C3-1-R (MINECO and FEDER), 19883/GERM/15 (Fundación Séneca de la Región de Murcia, Spain) and NODAMED (IEO).

Conflicts of Interest: The authors declare no conflict of interest.

\section{References}

1. Food and Agriculture Organization (FAO). The State of World Fisheries and Aquaculture; FAO: Rome, Italy, 2016; 200p.

2. Fukuda, Y.; Nguyen, H.D.; Furuhashi, M.; Nakai, T. Mass mortality of cultured sevenband grouper, Epinephelus septemfasciatus, associated with viral nervous necrosis. Fish Pathol. 1996, 31, 165-170. [CrossRef]

3. Grau, A.; Crespo, S.; Pastor, E.; Gonzalez, P.; Carbonell, E. High infection by Zeuxapta seriolae (Monogenea: Heteraxinidae) associated with mass mortalities of amberjack Seriola dumerili Risso reared in sea cages in the Balearic Islands (western Mediterranean). Bull. Eur. Assoc. Fish Pathol. 2003, 23, 139-142. 
4. Villamil, L.; Figueras, A.; Toranzo, A.E.; Planas, M.; Novoa, B. Isolation of a highly pathogenic Vibrio pelagius strain associated with mass mortalities of turbot, Scophthalmus maximus (L.), larvae. J. Fish Dis. 2003, 26, 293-303. [CrossRef] [PubMed]

5. Kibenge, F.S.B.; Godoy, M.G. Aquaculture Virology; Academic Press: London, UK, 2016; 568p, ISBN 9780128015735.

6. Klein, S.L. Hormonal and immunological mechanisms mediating sex differences in parasite infection. Parasite Immunol. 2004, 26, 247-264. [CrossRef] [PubMed]

7. Hecker, M.; Karbe, L. Parasitism in fish: An endocrine modulator of ecological relevance? Aquat. Toxicol. 2005, 72, 195-207. [CrossRef] [PubMed]

8. Deane, E.E.; Li, J.; Woo, N.Y.S. Hormonal status and phagocytic activity in sea bream infected with vibriosis. Comp. Biochem. Physiol. B Biochem. Mol. Biol. 2001, 129, 687-693. [CrossRef]

9. Wenger, M.; Shved, N.; Akgül, G.; Caelers, A.; Casanova, A.; Segner, H.; Eppler, E. Developmental oestrogen exposure differentially modulates IGF-I and TNF- $\alpha$ expression levels in immune organs of Yersinia ruckeri-challenged young adult rainbow trout (Oncorhynchus mykiss). Gen. Comp. Endocrinol. 2014, 205, 168-175. [CrossRef] [PubMed]

10. Engelsma, M.Y.; Huising, M.O.; van Muiswinkel, W.B.; Flik, G.; Kwang, J.; Savelkoul, H.F.; Verburg-van Kemenade, B.M. Neuroendocrine-immune interactions in fish: A role for interleukin-1. Vet. Immunol. Immunopathol. 2002, 87, 467-479. [CrossRef]

11. Harris, J.; Bird, D.J. Modulation of the fish immune system by hormones. Vet. Immunol. Immunopathol. 2000, 77, 163-176. [CrossRef]

12. Lutton, B.; Callard, I. Evolution of reproductive-immune interactions. Integr. Comp. Biol. 2006, 46, 1060-1071. [CrossRef] [PubMed]

13. Segner, H.; Verburg-van Kemenade, B.M.L.; Chadzinska, M. The immunomodulatory role of the hypothalamus-pituitary-gonad axis: Proximate mechanism for reproduction-immune trade offs? Dev. Comp. Immunol. 2017, 66, 43-60. [CrossRef] [PubMed]

14. Chaves-Pozo, E.; García-Ayala, A.; Cabas, I. Effects of sex steroids on fish leukocytes. Biology 2018, 7, 9. [CrossRef] [PubMed]

15. Iwanowicz, L.R.; Ottinger, C.A. Estrogens, estrogen receptors and their role as immunoregulators in fish. In Fish Defenses; Zaccone, G., Meseguer, J., Garcia Ayala, A., Kapoor, B.G., Eds.; Science Publisher: Enfield, UK, 2009; Volume 1, pp. 277-322. ISBN 978-1-57-808-327-5.

16. Verburg-van Kemenade, B.M.L.; Cohen, N.; Chadzinska, M. Neuroendocrine-immune interaction: Evolutionarily conserved mechanisms that maintain allostasis in an ever-changing environment. Dev. Comp. Immunol. 2017, 66. [CrossRef] [PubMed]

17. Szwejser, E.; Verburg-van Kemenade, B.M.L.; Maciuszek, M.; Chadzinska, M. Estrogen-dependent seasonal adaptations in the immune response of fish. Horm. Behav. 2017, 88, 15-24. [CrossRef] [PubMed]

18. Hedger, M.P. Macrophages and the immune responsiveness of the testis. J. Reprod. Immunol. 2002, 57, 19-34. [CrossRef]

19. Dunbar, B.S.; Prasad, S.; Carino, C.; Skinner, S.M. The ovary as an immune target. J. Soc. Gynecol. Investig. 2001, 8, S43-S48. [PubMed]

20. Bukulmez, O.; Arici, A. Leukocytes in ovarian function. Hum. Reprod. Update 2000, 6, 1-15. [CrossRef] [PubMed]

21. Fijak, M.; Meinhardt, A. The testis in immune privilege. Immunol. Rev. 2006, 213, 66-81. [CrossRef] [PubMed]

22. Hedger, M.P. Immune Privilege of the testis: Meaning, mechanisms, and manifestations. In Infection, Immune Homeostasis and Immune Privilege, Birkhäuser Advances in Infectious Diseases; Stein-Streilein, J., Ed.; Springer: Basel, Switzerland, 2012.

23. Wen, Q.; Tang, E.I.; Gao, Y.; Jesus, T.T.; Chu, D.S.; Lee, W.M.; Wong, C.K.C.; Liu, Y.-X.; Xiao, X.; Silvestrini, B.; et al. Signaling pathways regulating blood-tissue barriers-Lesson from the testis. Biochim. Biophys. Acta Biomembr. 2018, 1860, 141-153. [CrossRef] [PubMed]

24. Russell, L. Movement of spermatocytes from the basal to the adluminal compartment of the rat testis. Am. J. Anat. 1977, 148, 313-328. [CrossRef] [PubMed]

25. Su, L.; Mruk, D.D.; Cheng, C.Y. Drug transporters, the blood-testis barrier, and spermatogenesis. J. Endocrinol. 2011, 208, 207-223. [CrossRef] [PubMed] 
26. Smith, B.E.; Braun, R.E. Germ cell migration across Sertoli cell tight junctions. Science 2012, 338, 798-802. [CrossRef] [PubMed]

27. França, L.R.; Hess, R.A.; Dufour, J.M.; Hofmann, M.C.; Griswold, M.D. The Sertoli cell: One hundred fifty years of beauty and plasticity. Andrology 2016, 4, 189-212. [CrossRef] [PubMed]

28. Govero, J.; Esakky, P.; Scheaffer, S.M.; Fernandez, E.; Drury, A.; Platt, D.J.; Gorman, M.J.; Richner, J.M.; Caine, E.A.; Salazar, V.; et al. Zika virus infection damages the testes in mice. Nature 2016, 540, 438-442. [CrossRef] [PubMed]

29. Houzet, L.; Matusali, G.; Dejucq-Rainsford, N. Origins of HIV-infected leukocytes and virions in semen. J. Infect. Dis. 2014, 210, S622-S630. [CrossRef] [PubMed]

30. Jenabian, M.; Costiniuk, C.T.; Mehraj, V.; Ghazawi, F.M.; Fromenti, R.; Brousseau, J.; Brassard, P.; B'elanger, M.; Ancuta, P.; Bendayan, R.; et al. Immune tolerance properties of the testicular tissue as a viral sanctuary site in Art-treated Hiv-infected adults. Aids 2016, 30, 2777-2786. [CrossRef] [PubMed]

31. Risley, M.S.; Tan, I.P.; Roy, C.; Saez, J.C. Cell-, age- and stage-dependent distribution of connexin 43 gap junctions in testes. J. Cell Sci. 1992, 103, 81-96. [PubMed]

32. Batlouni, S.R.; Nóbrega, R.H.; França, L.R. Cell junctions in fish seminiferous epithelium. Fish Physiol. Biochem. 2009, 35, 207-217. [CrossRef] [PubMed]

33. Schulz, R.W.; de França, L.R.; Lareyre, J.J.; LeGac, F.; Chiarini-García, H.; Nobrega, R.H.; Miura, T. Spermatogenesis in fish. Gen. Comp. Endocrinol. 2010, 165, 390-411. [CrossRef] [PubMed]

34. Vogl, A.W.; Pfeiffer, D.C.; Mulholland, D.; Kimel, G.; Guttman, J. Unique and multifunctional adhesion junctions in the testis. Ectoplasmic specializations. Arch. Histol. Cytol. 2000, 63, 1-15. [CrossRef] [PubMed]

35. Abraham, M.; Rahamim, E.; Tibika, H.; Golenser, E.; Kieselskin, M. The blood-testis barrier in Aphanius dispar (Teleostei). Cell Tissue Res. 1980, 211, 207-214. [CrossRef] [PubMed]

36. Silva, M.; Godinho, H.P. Timing of some events of the gametogenesis in the male nile tilapia, Sarotherodon niloticus. Arch. dÁnatomie Microsc. 1983, 72, 231-237.

37. Callard, G.V.; Callard, I.P. Spermatogenesis, in nonmammals. In Encyclopedia of Reproduction; Knobil, E., Neil, J.D., Eds.; Academic Press: New York, NY, USA, 1999; Volume 4, pp. 563-570.

38. Batlouni, S.R.; Carreño, F.R.; Romagosa, E.; Borella, M.I. Cell junctions in the germinal epithelium may play an important role in spermatogenesis of the catfish P. fasciatum (Pisces, Siluriformes). J. Mol. Histol. 2005, 36, 97-110. [CrossRef] [PubMed]

39. Head, J.R.; Neaves, W.B.; Billingham, R.E. Reconsideration of the lymphatic drainage of the rat testis. Transplantation 1983, 35, 91-95. [CrossRef] [PubMed]

40. Möller, R. Arrangement and fine structure of lymphatic vessels in the human spermatic cord. Andrologia 2009, 12, 564-576. [CrossRef]

41. Itoh, M.; Li, X.; Yano, A.; Xie, Q.; Takeuchi, Y. Patterns of efferent lymphatics of the mouse testis. J. Androl. 1998, 19, 466-472. [CrossRef] [PubMed]

42. Ferguson, J.; Scothornet, R.J. Extended survival of pancreatic islet allografts in the testis of guinea-pigs. J. Anat. 1977, 124, 1. [PubMed]

43. Bobzien, B.; Yasunami, Y.; Majercik, M.; Lacy, P.E.; Davie, J.M. Intratesticular transplants of islet xenografts (rat to mouse). Diabetes 1983, 32, 213-216. [CrossRef] [PubMed]

44. Head, J.R.; Neaves, W.B.; Billingham, R.E. Immune privilege in the testis. I. Basic parameters of allograft survival. Transplantation 1983, 36, 423-431. [CrossRef] [PubMed]

45. Yule, T.D.; Montoya, G.D.; Russell, L.D.; Williams, T.M.; Tung, K.S. Autoantigenic germ cells exist outside the blood testis barrier. J. Immunol. 1988, 141, 1161-1167. [PubMed]

46. Hedger, M.P.; Hettiarachchi, S. Measurement of immunoglobulin g levels in adult rat testicular interstitial fluid and serum. J. Androl. 1994, 15, 583-590. [CrossRef] [PubMed]

47. Pöllänen, P.; Saari, T.; Yeung, C.-H.; Cooper, T.G. Regulation of the transport of immunoglobulin G into the male rat reproductive tract. J. Reprod. Immunol. 1995, 28, 111-135. [CrossRef]

48. Mclay, R.N.; Banks, W.A.; Kastin, A.J. Granulocyte macrophage-colony stimulating factor crosses the blood-testis barrier in mice. Biol. Reprod. 1997, 57, 822-826. [CrossRef] [PubMed]

49. Chaves-Pozo, E.; Liarte, S.; García-Ayala, A. Immune and reproductive interaction: An essential clue for understanding gonad functions in gilthead seabream. In Recent Advances in Fish Reproductive Biology; García-Ayala, A., Meseguer, J., Chaves-Pozo, E., Eds.; Research Signpost: Kerala, India, 2010; pp. 127-139. ISBN 978-81-308-0397-5. 
50. García-García, M.; Liarte, S.; Gómez-González, N.E.; García-Alcázar, A.; Pérez-Sánchez, J.; Meseguer, J.; Mulero, V.; García-Ayala, A.; Chaves-Pozo, E. Cimetidine disrupts the renewal of testicular cells and the steroidogenesis in a hermaphrodite fish. Comp. Biochem. Physiol. C Toxicol. Pharmacol. 2016, 189, 44-53. [CrossRef] [PubMed]

51. Valero, Y.; Sánchez-Hernández, M.; García-Alcázar, A.; García-Ayala, A.; Cuesta, A.; Chaves-Pozo, E. Characterization of the annual regulation of reproductive and immune parameters on the testis of European sea bass. Cell Tissue Res. 2015, 362, 215-229. [CrossRef] [PubMed]

52. Wang, D.-S.; Jiao, B.; Hu, C.; Huang, X.; Liu, Z.; Cheng, C.H.K. Discovery of a gonad-specific IGF subtype in teleost. Biochem. Biophys. Res. Commun. 2008, 367, 336-341. [CrossRef] [PubMed]

53. Zou, J.; Tafalla, C.; Truckle, J.; Secombes, C.J. Identification of a second group of type I IFNs in fish sheds light on IFN evolution in vertebrates. J. Immunol. 2007, 179, 3859-3871. [CrossRef] [PubMed]

54. Purcell, M.K.; Laing, K.J.; Woodson, J.C.; Thorgaard, G.H.; Hansen, J.D. Characterization of the interferon genes in homozygous rainbow trout reveals two novel genes, alternate splicing and differential regulation of duplicated genes. Fish Shellfish Immunol. 2009, 26, 293-304. [CrossRef] [PubMed]

55. Chaves-Pozo, E.; Zou, J.; Secombes, C.J.; Cuesta, A.; Tafalla, C. The rainbow trout (Oncorhynchus mykiss) interferon response in the ovary. Mol. Immunol. 2010, 47, 1757-1764. [CrossRef] [PubMed]

56. Li, Z.; Hong, W.S.; Qiu, H.T.; Zhang, Y.T.; Yang, M.S.; You, X.X.; Chen, S.X. Cloning and expression of two hepcidin genes in the mudskipper (Boleophthalmus pectinirostris) provides insights into their roles in male reproductive immunity. Fish Shellfish Immunol. 2016, 56, 239-247. [CrossRef] [PubMed]

57. Jin, J.-Y.; Zhou, L.; Wang, Y.; Li, Z.; Zhao, J.-G.; Zhang, Q.-Y.; Gui, J.-F. Antibacterial and antiviral roles of a fish $\beta$-defensin expressed both in pituitary and testis. PLOS ONE 2010, 5, e12883. [CrossRef] [PubMed]

58. Mital, P.; Kaur, G.; Dufour, J.M. Immunoprotective sertoli cells: Making allogeneic and xenogeneic transplantation feasible. Reproduction 2010, 139, 495-504. [CrossRef] [PubMed]

59. Nasr, I.W.; Wang, Y.; Gao, G.; Deng, S.; Diggs, L.; Rothstein, D.M.; Tellides, G.; Lakkis, F.G.; Dai, Z. Testicular immune privilege promotes transplantation tolerance by altering the balance between memory and regulatory T cells. J. Immunol. 2005, 174, 6161-6168. [CrossRef] [PubMed]

60. Fijak, M.; Schneider, E.; Klug, J.; Bhushan, S.; Hackstein, H.; Schuler, G.; Wygrecka, M.; Gromoll, J.; Meinhardt, A. Testosterone replacement effectively inhibits the development of experimental autoimmune orchitis in rats: Evidence for a direct role of testosterone on regulatory T cell expansion. J. Immunol. 2011, 186, 5162-5172. [CrossRef] [PubMed]

61. Chaves-Pozo, E.; Mulero, V.; Meseguer, J.; Garcia Ayala, A.; García-Ayala, A. Professional phagocytic granulocytes of the bony fish gilthead seabream display functional adaptation to testicular microenvironment. J. Leukoc. Biol. 2005, 78, 345-351. [CrossRef] [PubMed]

62. Chaves-Pozo, E.; Liarte, S.; Fernández-Alacid, L.; Abellán, E.; Meseguer, J.; Mulero, V.; García-Ayala, A. Pattern of expression of immune-relevant genes in the gonad of a teleost, the gilthead seabream (Sparus aurata L.). Mol. Immunol. 2008, 45, 2998-3011. [CrossRef] [PubMed]

63. Jin, H.J.; Shao, J.Z.; Xiang, L.X. Identification and characterization of suppressor of cytokine signaling 3 (SOCS-3) homologues in teleost fish. Mol. Immunol. 2007, 44, 1042-1051. [CrossRef] [PubMed]

64. Jin, H.J.; Xiang, L.X.; Shao, J.Z. Identification and characterization of suppressor of cytokine signaling 1 (SOCS-1) homologues in teleost fish. Immunogenetics 2007, 59, 673-686. [CrossRef] [PubMed]

65. Cabas, I.; Chaves-Pozo, E.; García-Alcázar, A.; Meseguer, J.; Mulero, V.; García-Ayala, A. Dietary intake of 17alpha-ethinylestradiol promotes leukocytes infiltration in the gonad of the hermaphrodite gilthead seabream. Mol. Immunol. 2011, 48, 2079-2086. [CrossRef] [PubMed]

66. Chaves-Pozo, E.; Liarte, S.; Vargas-Chacoff, L.; García-López, A.; Mulero, V.; Meseguer, J.; Mancera, J.M.; García-Ayala, A. 17Beta-estradiol triggers postspawning in spermatogenically active gilthead seabream (Sparus aurata L.) males. Biol Reprod. 2007, 76, 142-148. [CrossRef] [PubMed]

67. Sánchez-Hernández, M.; Chaves-Pozo, E.; Cabas, I.; Mulero, V.; García-Ayala, A.; García-Alcázar, A. Testosterone implants modify the steroid hormone balance and the gonadal physiology of gilthead seabream (Sparus aurata L.) males. J. Steroid. Biochem. Mol. Biol. 2013, 138C, 183-194. [CrossRef] [PubMed]

68. Cabas, I.; Chaves-Pozo, E.; García-Alcázar, A.; Meseguer, J.; Mulero, V.; García-Ayala, A. The effect of 17alpha-ethynylestradiol on steroidogenesis and gonadal cytokine gene expression is related to the reproductive stage in marine hermaphrodite fish. Mar. Drugs 2013, 11, 4973-4992. [CrossRef] [PubMed] 
69. Li, X.; Strauss, L.; Kaatrasalo, A.; Mayerhofer, A.; Huhtaniemi, I.; Santti, R.; Mäkelä, S.; Poutanen, M. Transgenic Mice expressing P450 aromatase as a model for male infertility associated with chronic inflammation in the testis. Endocrinology 2006, 147, 1271-1277. [CrossRef] [PubMed]

70. Yoshimura, Y.; Barua, A. Female reproductive system and immunology. In Avian Reproduction, Advances in Experimental Medicine and Biology; Springer: Singapore, 2017; pp. 33-57.

71. Lutton, B.V.; Callard, I.P. Morphological relationships and leukocyte influence on steroid production in the epigonal organ-ovary complex of the skate, Leucoraja erinacea. J. Morphol. 2008, 269, 620-629. [CrossRef] [PubMed]

72. Chaves-Pozo, E.; Liarte, S.; Mulero, I.; Abellán, E.; Meseguer, J.; García-Ayala, A.; Abellan, E.; Meseguer, J.; Garcia-Ayala, A. Early presence of immune cells in the developing gonad of the gilthead seabream (Sparus aurata Linnaeus, 1758). J. Reprod. Dev. 2009, 55, 440-445. [CrossRef] [PubMed]

73. Liarte, S.; Chaves-Pozo, E.; García-Alcázar, A.; Mulero, V.; Meseguer, J.; García-Ayala, A. Testicular involution prior to sex change in gilthead seabream is characterized by a decrease in DMRT1 gene expression and by massive leukocyte infiltration. Reprod. Biol. Endocrinol. 2007, 5, 20. [CrossRef] [PubMed]

74. Zhang, L.; Gallo, R.L. Antimicrobial peptides. Curr. Biol. 2016, 26, R14-R19. [CrossRef] [PubMed]

75. Valero, Y.; García-Alcázar, A.; Esteban, M.A.; Cuesta, A.; Chaves-Pozo, E.; García-Alcazar, A.; Esteban, M.A.; Cuesta, A.; Chaves-Pozo, E. Antimicrobial response is increased in the testis of European sea bass, but not in gilthead seabream, upon nodavirus infection. Fish Shellfish Immunol. 2015, 44, 203-213. [CrossRef] [PubMed]

76. Grandjean, V.; Vincent, S.; Martin, L.; Rassoulzadegan, M.; Cuzin, F. Antimicrobial protection of the mouse testis: Synthesis of defensins of the cryptdin family. Biol. Reprod. 1997, 57, 1115-1122. [CrossRef] [PubMed]

77. Silphaduang, U.; Hincke, M.T.; Nys, Y.; Mine, Y. Antimicrobial proteins in chicken reproductive system. Biochem. Biophys. Res. Commun. 2006, 340, 648-655. [CrossRef] [PubMed]

78. King, A.E.; Critchley, H.O.; Kelly, R.W. Innate immune defences in the human endometrium. Reprod. Biol. Endocrinol. 2003, 1, 116. [CrossRef] [PubMed]

79. King, A.E.; Fleming, D.C.; Critchley, H.O.; Kelly, R.W. Differential expression of the natural antimicrobials, beta-defensins 3 and 4, in human endometrium. J. Reprod. Immunol. 2003, 59, 1-16. [CrossRef]

80. Rodríguez, A.; Esteban, M.A.; Meseguer, J. Phagocytosis and peroxidase release by seabream (Sparus aurata L.) leucocytes in response to yeast cells. Anat. Rec. A Discov. Mol. Cell. Evol. Biol. 2003, 272, 415-423. [CrossRef] [PubMed]

81. Ortuño, J.; Esteban, M.A.; Meseguer, J. Kinetics of hydrogen peroxide production during in vitro respiratory burst of seabream (Sparus aurata L.) head-kidney leucocytes, as measured by a flow cytometric method. Fish Shellfish Immunol. 2000, 10, 725-729. [CrossRef] [PubMed]

82. Cuesta, A.; Esteban, M.A.; Meseguer, J. Natural cytotoxic activity of gilthead seabream (Sparus aurata L.) leucocytes. Assessment by flow cytometry and microscopy. Vet. Immunol. Immunopathol. 1999, 71, 161-171. [CrossRef]

83. Secombes, C.J. Immunological activation of rainbow trout macrophages induced in vitro by sperm autoantibodies and factors derived from testis sensitised leucocytes. Vet. Immunol. Immunopathol. 1986, 12, 193-201. [CrossRef]

84. Saito, E.; Nakamura, O.; Yamada, H.; Tsutsui, S.; Watanabe, T. Suppression of lymphocyte proliferation by ovarian cavity fluid from the viviparous fish Neoditrema ransonnetii (Perciformes; Embiotocidae). Fish Shellfish Immunol. 2009, 27, 549-555. [CrossRef] [PubMed]

85. Cammarata, M.; Benenati, G.; Odom, E.W.; Salerno, G.; Vizzini, A.; Vasta, G.R.; Parrinello, N. Isolation and characterization of a fish F-type lectin from gilt head bream (Sparus aurata) serum. Biochim. Biophys. Acta 2007, 1770, 150-155. [CrossRef] [PubMed]

86. Dong, M.; Liang, Y.; Ramalingam, R.; Tang, S.W.; Shen, W.; Ye, R.; Gopalakrishnan, S.; Au, D.W.T.; Lam, Y.W. Proteomic characterization of the interactions between fish serum proteins and waterborne bacteria reveals the suppression of anti-oxidative defense as a serum-mediated antimicrobial mechanism. Fish Shellfish Immunol. 2017, 62, 96-106. [CrossRef] [PubMed]

87. An, J.; Liu, T.; She, R.; Wu, Q.; Tian, J.; Shi, R.; Hao, W.; Ren, X.; Yang, Y.; Lu, Y.; et al. Replication of hepatitis E virus in the ovary and promotion of oocyte apoptosis in rabbits infected with HEV-4. Oncotarget 2018, 9, 4475-4484. [CrossRef] [PubMed]

88. Song, B.-H.; Yun, S.-I.; Woolley, M.; Lee, Y.-M. Zika virus: History, epidemiology, transmission, and clinical presentation. J. Neuroimmunol. 2017, 308, 50-64. [CrossRef] [PubMed] 
89. Blaszkowska, J.; Goralska, K. Parasites and fungi as a threat for prenatal and postnatal human development. Ann. Parasitol. 2014, 60, 225-234. [PubMed]

90. Sheldon, I.M.; Owens, S.-E.; Turner, M.L. Innate immunity and the sensing of infection, damage and danger in the female genital tract. J. Reprod. Immunol. 2017, 119, 67-73. [CrossRef] [PubMed]

91. Armour, N.K.; Ferguson-Noel, N. Evaluation of the egg transmission and pathogenicity of Mycoplasma gallisepticum isolates genotyped as ts-11. Avian Pathol. 2015, 44, 296-304. [CrossRef] [PubMed]

92. Breuil, G.; Pepin, J.F.P.; Boscher, S.; Thiery, R. Experimental vertical transmission of nodavirus from broodfish to eggs and larvae of the sea bass, Dicentrarchus labrax (L.). J. Fish Dis. 2002, 25, 697-702. [CrossRef]

93. Kocan, R.M.; Hershberger, P.K.; Elder, N.E. Survival of the North American strain of viral hemorrhagic septicemia virus (VHSV) in filtered seawater and seawater containing ovarian fluid, crude oil and serum-enriched culture medium. Dis. Aquat. Organ. 2001, 44, 75-78. [CrossRef] [PubMed]

94. Sinyakov, M.S.; Belotsky, S.; Shlapobersky, M.; Avtalion, R.R. Vertical and horizontal transmission of tilapia larvae encephalitis virus: The bad and the ugly. Virology 2011, 410, 228-233. [CrossRef] [PubMed]

95. Smail, D.A.; Munro, E.S. Isolation and quantification of infectious pancreatic necrosis virus from ovarian and seminal fluids of Atlantic salmon, Salmo salar L. J. Fish Dis. 2008, 31, 49-58. [CrossRef] [PubMed]

96. Fioravanti, M.L.; Caffara, M.; Florio, D.; Gustinelli, A.; Marcer, F. Sphaerospora dicentrarchi and S. testicularis (Myxozoa: Sphaerosporidae) in farmed European seabass (Dicentrarchus labrax) from Italy. Folia Parasitol. 2004, 51, 208-210. [CrossRef] [PubMed]

97. Sitja-Bobadilla, A.; Alvarez-Pellitero, P. Population dynamics of Sphaerospora dicentrarchi Sitja-Bobadilla et Alvarez-Pellitero, 1992 and S. testicularis Sitja-Bobadilla et Alvarez-Pellitero, 1990 (Myxosporea: Bivalvulida) infections in wild and cultured Mediterranean sea bass (Dicentrarchus labrax L.). Parasitology 1993, 106, $39-45$. [PubMed]

98. Sitja-Bobadilla, A.; Alvarez-Pellitero, P. Pathologic effects of Sphaerospora dicentrarchi Sitjà-Bobadilla and Alvarez-Pellitero, 1992 and S. testicularis Sitjà-Bobadilla and Alvarez-Pellitero, 1990 (Myxosporea: Bivalvulida) parasitic in the Mediterranean sea bass Dicentrarchus labrax L. (Teleostei: Serranidae) and the cell-mediated immune reaction: A light and electron microscopy study. Parasitol. Res. 1993, 79, 119-129. [PubMed]

99. Alvarez-Pellitero, P.; Sitja-Bobadilla, A. Pathology of Myxosporea in marine fish culture. Dis. Aquat. Organ. 1993, 17, 229-238. [CrossRef]

100. Pappas, G. The changing Brucella ecology: Novel reservoirs, new threats. Int. J. Antimicrob. Agents 2010, 36 (Suppl. 1), S8-S11. [CrossRef] [PubMed]

101. Nymo, I.H.; Seppola, M.; Al Dahouk, S.; Bakkemo, K.R.; Jiménez de Bagüés, M.P.; Godfroid, J.; Larsen, A.K. Experimental challenge of Atlantic cod (Gadus morhua) with a Brucella pinnipedialis strain from Hooded seal (Cystophora cristata). PLoS ONE 2016, 11, e0159272. [CrossRef] [PubMed]

102. Taylor, P.W. Detection of Flavobacterium psychrophilum in eggs and sexual fluids of pacific salmonids by a polymerase chain reaction assay: Implications for vertical transmission of bacterial coldwater disease. J. Aquat. Anim. Health 2004, 16, 104-108. [CrossRef]

103. Brown, L.L.; Cox, W.T.; Levine, R.P. Evidence that the causal agent of bacterial cold-water disease Flavobacterium psychrophilum is transmitted within salmonid eggs. Dis. Aquat. Organ. 1997, 29, 213-218. [CrossRef]

104. Ekman, E.; Börjeson, H.; Johansson, N. Flavobacterium psychrophilum in Baltic salmon Salmo salar brood fish and their offspring. Dis. Aquat. Organ. 1999, 37, 159-163. [CrossRef] [PubMed]

105. Cipriano, R.C. Intraovum infection caused by Flavobacterium psychrophilum among eggs from captive Atlantic salmon broodfish. J. Aquat. Anim. Health 2005, 17, 275-283. [CrossRef]

106. Madsen, L.; Moller, J.D.; Dalsgaard, I. Flavobacterium psychrophilum in rainbow trout, Oncorhynchus mykiss (Walbaum), hatcheries: Studies on broodstock, eggs, fry and environment. J. Fish Dis. 2005, 28, 39-47. [CrossRef] [PubMed]

107. Chaves-Pozo, E.; Montero, J.; Cuesta, A.; Tafalla, C. Viral hemorrhagic septicemia and infectious pancreatic necrosis viruses replicate differently in rainbow trout gonad and induce different chemokine transcription profiles. Dev. Comp. Immunol. 2010, 34, 648-658. [CrossRef] [PubMed]

108. Al-Hussinee, L.; Lumsden, J.S. Detection of VHSV IVb withing the gonads of Great Lakes fish using in situ hybridization. Dis. Aquat. Organ. 2011, 95, 81-86. [CrossRef] [PubMed]

109. Ahne, W.; Negele, R.D. IPNV transmission via eyed eggs. In Fish and Shellfish Pathology; Ellis, A., Ed.; Academic Press: London, Orlando, USA, 1985; pp. 261-269. 
110. World Organisation for Animal Health. OIE, Aquatic Animal Health Code, 13rd ed.; OIE, Ed.; World Organisation for Animal Health: Paris, France, 2010; ISBN 978-92-9044-777-1.

111. Sitjà-Bobadilla, A.; Alvarez-Pellitero, P. Ultrastructural and cytochemical observations on the sporogenesis of Sphaerospora testicularis (Protozoa: Myxosporea) from Mediterranean sea bass, Dicentrarchus labrax (L.). Eur. J. Protistol. 1993, 29, 219-229. [CrossRef]

112. Mao, M.-G.; Wen, S.-H.; Perálvarez-Marín, A.; Li, H.; Jiang, J.-L.; Jiang, Z.-Q.; Li, X.; Sun, H.; Lü, H.-Q. Evidence for and characterization of nervous necrosis virus infection in Pacific cod (Gadus macrocephalus). Arch. Virol. 2015, 160, 2237-2248. [CrossRef] [PubMed]

113. Valero, Y.; Arizcun, M.; Esteban, M.A.; Bandín, I.; Olveira, J.G.; Patel, S.; Cuesta, A.; Chaves-Pozo, E. Nodavirus colonizes and replicates in the testis of gilthead seabream and European sea bass modulating its immune and reproductive functions. PLoS ONE 2015, 10, e0145131. [CrossRef] [PubMed]

114. Dalla Valle, L.; Zanella, L.; Patarnello, P.; Paolucci, L.; Belvedere, P.; Colombo, L. Development of a sensitive diagnostic assay for fish nervous necrosis virus based on RT-PCR plus nested PCR. J. Fish Dis. 2000, 23, 321-327. [CrossRef]

115. Mushiake, K.; Nishizawa, T.; Nakai, T.; Furusawa, I.; Muroga, K. Control of VNN in striped jack: Selection of spawners based on the detection of SJNNV gene by polymerase chain reaction (PCR). Fish Pathol. 1994, 29, 177-182. [CrossRef]

116. Shao, L.; Zhao, J.; Zhang, H. Spring viraemia of carp virus enters grass carp ovary cells via clathrin-mediated endocytosis and macropinocytosis. J. Gen. Virol. 2016, 97, 2824-2836. [CrossRef] [PubMed]

117. Suebsing, R.; Pradeep, P.J.; Jitrakorn, S.; Sirithammajak, S.; Kampeera, J.; Turner, W.A.; Saksmerprome, V.; Withyachumnarnkul, B.; Kiatpathomchai, W. Detection of natural infection of infectious spleen and kidney necrosis virus in farmed tilapia by hydroxynapthol blue-loop-mediated isothermal amplification assay. J. Appl. Microbiol. 2016, 121, 55-67. [CrossRef] [PubMed]

118. Dawar, F.U.; Hu, X.; Zhao, L.; Dong, X.; Xiong, Y.; Zhou, M.; Liang, R.; Sarath Babu, V.; Li, J.; Mei, J.; et al. Transcriptomic analysis reveals differentially expressed genes and a unique apoptosis pathway in channel catfish ovary cells after infection with the channel catfish virus. Fish Shellfish Immunol. 2017, 71, 58-68. [CrossRef] [PubMed]

119. Ahne, W.; Bjorklund, H.V.; Essbauer, S.; Fijan, N.; Kurath, G.; Winton, J.R. Spring viremia of carp (SVC). Dis. Aquat. Org. Dis. Aquat. Org. 2002, 52, 261-272. [CrossRef] [PubMed]

120. Nabi, I.R.; Le, P.U. Caveolae/raft-dependent endocytosis. J. Cell Biol. 2003, 161, 673-677. [CrossRef] [PubMed]

121. Guo, C.-J.; Wu, Y.-Y.; Yang, L.-S.; Yang, X.-B.; He, J.; Mi, S.; Jia, K.-T.; Weng, S.-P.; Yu, X.-Q.; He, J.-G. Infectious spleen and kidney necrosis virus (a fish iridovirus) enters Mandarin fish fry cells via caveola-dependent endocytosis. J. Virol. 2012, 86, 2621-2631. [CrossRef] [PubMed]

122. Hedrick, R.P.; McDowell, T.S.; Groff, J.M.; Yun, S.; Wingfield, W.H. Isolation and some properties of an iridovirus like agent from white sturgeon Acipenser transmontanus. Dis. Aquat. Organ. 1992, 12, 75-81. [CrossRef]

123. LaPatra, S.E.; Groff, J.M.; Jones, G.R.; Munn, B.; Patterson, T.L.; Holt, R.A.; Hauck, A.K.; Hedrick, R.P. Occurrence of white sturgeon iridovirus infections among cultured white sturgeon in the Pacific Northwest. Aquaculture 1994, 126, 201-210. [CrossRef]

124. Nylund, A.; Hovland, T.; Watanabe, K.; Endresen, C. Presence of infectious salmon anaemia virus (ISAV) in tissues of Atlantic salmon, Salmo salar L., collected during three separate outbreaks of the disease. J. Fish Dis. 1995, 18, 135-145. [CrossRef]

125. Marshall, S.H.; Ramírez, R.; Labra, A.; Carmona, M.; Muñoz, C. Bona fide evidence for natural vertical transmission of infectious salmon anemia virus in freshwater brood stocks of farmed Atlantic salmon (Salmo salar) in Southern Chile. J. Virol. 2014, 88, 6012-6018. [CrossRef] [PubMed]

126. Gomez-Casado, E.; Estepa, A.; Coll, J.M. A comparative review on European-farmed finfish RNA viruses and their vaccines. Vaccine 2011, 29, 2657-2671. [CrossRef] [PubMed]

127. Breuil, G.; Bonami, J.R.; Pepin, J.F.; Pichot, Y. Viral infection (picorna-like virus) associated with mass mortalities in hatchery-reared sea-bass (Dicentrarchus labrax) larvae and juveniles. Aquaculture 1991, 97, 109-116. [CrossRef]

128. Grotmol, S.; Bergh, O.; Totland, G.K. Transmission of viral encephalopathy and retinopathy (VER) to yolk-sac larvae of the Atlantic halibut Hippoglossus hippoglossus: Occurrence of nodavirus in various organs and a possible route of infection. Dis. Aquat. Organ. 1999, 36, 95-106. [CrossRef] [PubMed] 
129. Korsnes, K.; Karlsbakk, E.; Nylund, A.; Nerland, A.H. Horizontal transmission of nervous necrosis virus between turbot Scophthalmus maximus and Atlantic cod Gadus morhua using cohabitation challenge. Dis. Aquat. Organ. 2012, 99, 13-21. [CrossRef] [PubMed]

130. Kuo, H.C.; Wang, T.Y.; Hsu, H.H.; Chen, P.P.; Lee, S.H.; Chen, Y.M.; Tsai, T.J.; Wang, C.K.; Ku, H.T.; Lee, G.B.; et al. Nervous necrosis virus replicates following the embryo development and dual infection with iridovirus at juvenile stage in grouper. PLoS ONE 2012, 7, e36183. [CrossRef] [PubMed]

131. Watanabe, K.I.; Nishizawa, T.; Yoshimizu, M. Selection of brood stock candidates of barfin flounder using an ELISA system with recombinant protein of barfin flounder nervous necrosis virus. Dis. Aquat. Organ. 2000, 41, 219-223. [CrossRef] [PubMed]

132. Chaves-Pozo, E.; Guardiola, F.A.; Meseguer, J.; Esteban, M.A.; Cuesta, A. Nodavirus infection induces a great innate cell-mediated cytotoxic activity in resistant, gilthead seabream, and susceptible, European sea bass, teleost fish. Fish Shellfish Immunol. 2012, 33, 1159-1166. [CrossRef] [PubMed]

133. Valero, Y.; Boughlala, B.; Arizcun, M.; Patel, S.; Fiksdal, I.U.; Esteban, M.Á.; De Juan, J.; Meseguer, J.; Chaves-Pozo, E.; Cuesta, A. Genes related to cell-mediated cytotoxicity and interferon response are induced in the retina of European sea bass upon intravitreal infection with nodavirus. Fish Shellfish Immunol. 2018, 74, 627-636. [CrossRef] [PubMed]

134. Valero, Y.; Arizcun, M.; Esteban, M.Á.; Cuesta, A.; Chaves-Pozo, E. Transcription of histones H1 and H2B is regulated by several immune stimuli in gilthead seabream and European sea bass. Fish Shellfish Immunol. 2016, 57, 107-115. [CrossRef] [PubMed]

135. Valero, Y.; Morcillo, P.; Meseguer, J.; Buonocore, F.; Esteban, M.A.; Chaves-Pozo, E.; Cuesta, A. Characterization of the interferon pathway in the teleost fish gonad against the vertically transmitted viral nervous necrosis virus. J. Gen. Virol. 2015, 96, 2176-2187. [CrossRef] [PubMed]

136. Cordero, H.; Li, C.H.; Chaves-Pozo, E.; Esteban, M.Á.; Cuesta, A. Molecular identification and characterization of haptoglobin in teleosts revealed an important role on fish viral infections. Dev. Comp. Immunol. 2017, 76, 189-199. [CrossRef] [PubMed]

137. Tokarz, J.; Möller, G.; Hrabě de Angelis, M.; Adamski, J. Steroids in teleost fishes: A functional point of view. Steroids 2015, 103, 123-144. [CrossRef] [PubMed]

138. Cabas, I.; Rodenas, M.C.; Abellan, E.; Meseguer, J.; Mulero, V.; Garcia-Ayala, A.; Abellán, E.; Meseguer, J.; Mulero, V.; García-Ayala, A. Estrogen signaling through the G protein-coupled estrogen receptor regulates granulocyte activation in fish. J. Immunol. 2013, 191, 4628-4639. [CrossRef] [PubMed]

139. Kovats, S. Estrogen receptors regulate innate immune cells and signaling pathways. Cell. Immunol. 2015, 294, 63-69. [CrossRef] [PubMed]

140. Liarte, S.; Chaves-Pozo, E.; Abellán, E.; Meseguer, J.; Mulero, V.; Canario, A.V.; García-Ayala, A. Estrogen-responsive genes in macrophages of the bony fish gilthead seabream: A transcriptomic approach. Dev. Comp. Immunol. 2011, 35, 840-849. [CrossRef] [PubMed]

141. Liarte, S.; Cabas, I.; Chaves-Pozo, E.; Arizcun, M.; Meseguer, J.; Mulero, V.; García-Ayala, A. Natural and synthetic estrogens modulate the inflammatory response in the gilthead seabream (Sparus aurata L.) through the activation of endothelial cells. Mol. Immunol. 2011, 48, 1917-1925. [CrossRef] [PubMed]

142. López-Muñoz, A.; Liarte, S.; Gómez-González, N.E.; Cabas, I.; Meseguer, J.; García-Ayala, A.; Mulero, V. Estrogen receptor $2 \mathrm{~b}$ deficiency impairs the antiviral response of zebrafish. Dev. Comp. Immunol. 2015, 53, 55-62. [CrossRef] [PubMed]

143. Roa, J.; Navarro, V.M.; Tena-Sempere, M. Kisspeptins in reproductive biology: Consensus knowledge and recent developments. Biol. Reprod. 2011, 85, 650-660. [CrossRef] [PubMed]

144. Migaud, H.; Ismail, R.; Cowan, M.; Davie, A. Kisspeptin and seasonal control of reproduction in male European sea bass (Dicentrarchus labrax ). Gen. Comp. Endocrinol. 2012, 179, 384-399. [CrossRef] [PubMed]

145. Escobar, S.; Felip, A.; Gueguen, M.M.; Zanuy, S.; Carrillo, M.; Kah, O.; Servili, A. Expression of kisspeptins in the brain and pituitary of the european sea bass (Dicentrarchus labrax). J. Comp. Neurol. 2013, 521, 933-948. [CrossRef] [PubMed]

(C) 2018 by the authors. Licensee MDPI, Basel, Switzerland. This article is an open access article distributed under the terms and conditions of the Creative Commons Attribution (CC BY) license (http:/ / creativecommons.org/licenses/by/4.0/). 